\title{
Natural and Human Influences on Water Quality in a Shallow Regional Unconsolidated Aquifer, Northern Atlantic Coastal Plain
}

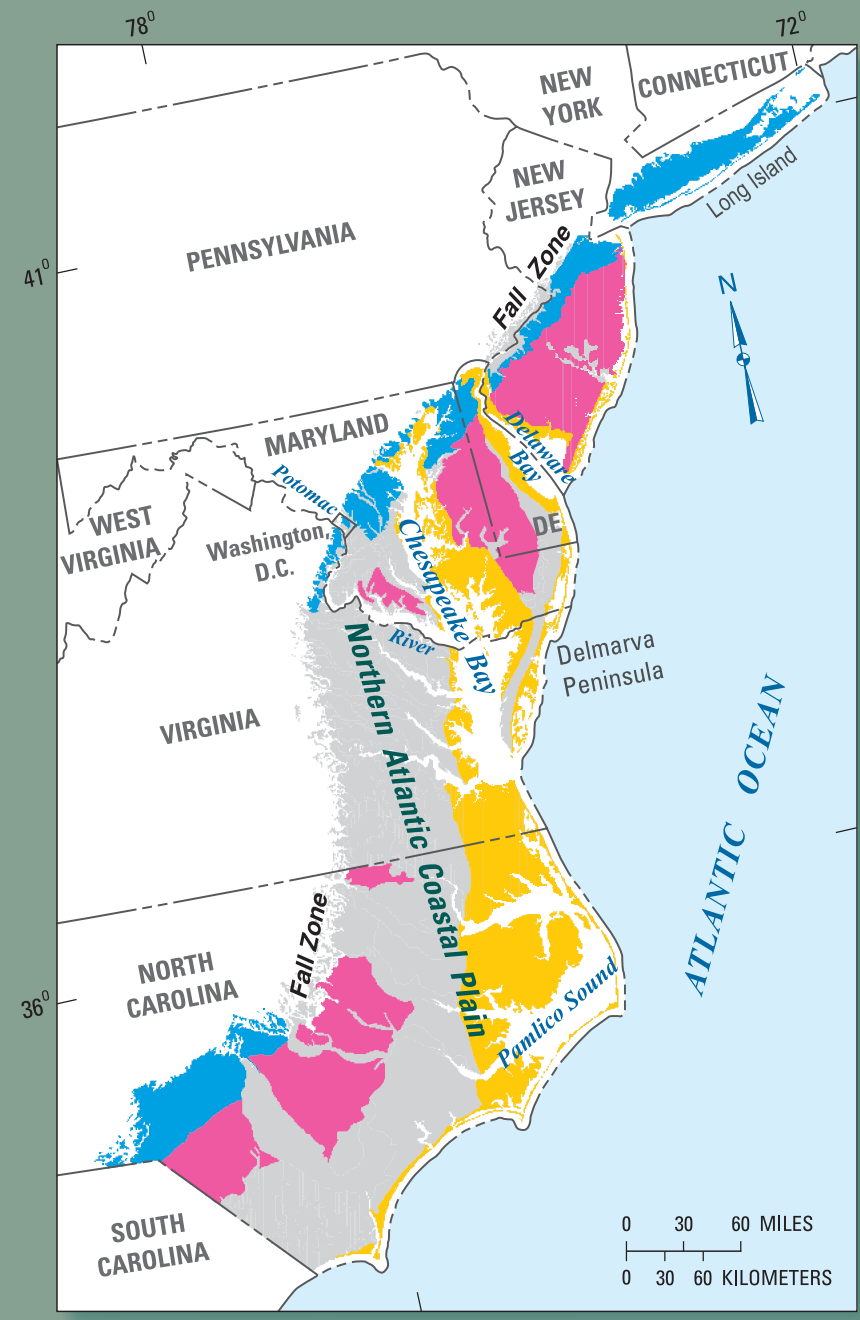

Scientific Investigations Report 2008-5190 
Cover. Selected hydrogeologic settings (Coastal Lowlands, and parts of the Middle and Inner Coastal Plain) in the Northern Atlantic Coastal Plain. 


\section{Natural and Human Influences on Water Quality in a Shallow Regional Unconsolidated Aquifer, Northern Atlantic Coastal Plain}

By Scott W. Ator

National Water-Quality Assessment Program

Scientific Investigations Report 2008-5190 


\title{
U.S. Department of the Interior DIRK KEMPTHORNE, Secretary
}

\author{
U.S. Geological Survey \\ Mark D. Myers, Director
}

U.S. Geological Survey, Reston, Virginia: 2008

For product and ordering information:

World Wide Web: http://www.usgs.gov/pubprod

Telephone: 1-888-ASK-USGS

For more information on the USGS — the Federal source for science about the Earth,

its natural and living resources, natural hazards, and the environment:

World Wide Web: http://www.usgs.gov

Telephone: 1-888-ASK-USGS

Suggested citation:

Ator, S.W., 2008, Natural and human influences on water quality in a shallow regional unconsolidated aquifer, Northern Atlantic Coastal Plain: U.S. Geological Survey Scientific Investigations Report 2008-5190, 19 p.

Any use of trade, product, or firm names is for descriptive purposes only and does not imply endorsement by the U.S. Government. Use of company names is for identification purposes only and does not imply responsibility.

Although this report is in the public domain, permission must be secured from the individual copyright owners to reproduce any copyrighted material contained within this report. 


\section{Foreword}

The U.S. Geological Survey (USGS) is committed to providing the Nation with credible scientific information that helps to enhance and protect the overall quality of life and that facilitates effective management of water, biological, energy, and mineral resources (http://www.usgs.gov/. Information on the Nation's water resources is critical to ensuring long-term availability of water that is safe for drinking and recreation and is suitable for industry, irrigation, and fish and wildlife. Population growth and increasing demands for water make the availability of that water, now measured in terms of quantity and quality, even more essential to the long-term sustainability of our communities and ecosystems.

The USGS implemented the National Water-Quality Assessment (NAWQA) Program in 1991 to support national, regional, State, and local information needs and decisions related to water-quality management and policy (http://water.usgs.gov/nawqa). The NAWQA Program is designed to answer: What is the condition of our Nation's streams and ground water? How are conditions changing over time? How do natural features and human activities affect the quality of streams and ground water, and where are those effects most pronounced? By combining information on water chemistry, physical characteristics, stream habitat, and aquatic life, the NAWQA Program aims to provide science-based insights for current and emerging water issues and priorities. From 1991-2001, the NAWQA Program completed interdisciplinary assessments and established a baseline understanding of water-quality conditions in 51 of the Nation's river basins and aquifers, referred to as Study Units (http://water.usgs.gov/nawqa/studyu.htm/.

In the second decade of the Program (2001-2012), a major focus is on regional assessments of waterquality conditions and trends. These regional assessments are based on major river basins and principal aquifers, which encompass larger regions of the country than the Study Units. Regional assessments extend the findings in the Study Units by filling critical gaps in characterizing the quality of surface water and ground water, and by determining status and trends at sites that have been consistently monitored for more than a decade. In addition, the regional assessments continue to build an understanding of how natural features and human activities affect water quality. Many of the regional assessments employ modeling and other scientific tools, developed on the basis of data collected at individual sites, to help extend knowledge of water quality to unmonitored, yet comparable areas within the regions. The models thereby enhance the value of our existing data and our understanding of the hydrologic system. In addition, the models are useful in evaluating various resource-management scenarios and in predicting how our actions, such as reducing or managing nonpoint and point sources of contamination, land conversion, and altering flow and (or) pumping regimes, are likely to affect water conditions within a region.

Other activities planned during the second decade include continuing national syntheses of information on pesticides, volatile organic compounds (VOCs), nutrients, selected trace elements, and aquatic ecology; and continuing national topical studies on the fate of agricultural chemicals, effects of urbanization on stream ecosystems, bioaccumulation of mercury in stream ecosystems, effects of nutrient enrichment on stream ecosystems, and transport of contaminants to public-supply wells.

The USGS aims to disseminate credible, timely, and relevant science information to address practical and effective water-resource management and strategies that protect and restore water quality. We hope this NAWQA publication will provide you with insights and information to meet your needs, and will foster increased citizen awareness and involvement in the protection and restoration of our Nation's waters.

The USGS recognizes that a national assessment by a single program cannot address all water-resource issues of interest. External coordination at all levels is critical for cost-effective management, regulation, and conservation of our Nation's water resources. The NAWQA Program, therefore, depends on advice and information from other agencies—Federal, State, regional, interstate, Tribal, and local—as well as nongovernmental organizations, industry, academia, and other stakeholder groups. Your assistance and suggestions are greatly appreciated.

Matthew C. Larsen

Associate Director for Water 



\section{Contents}

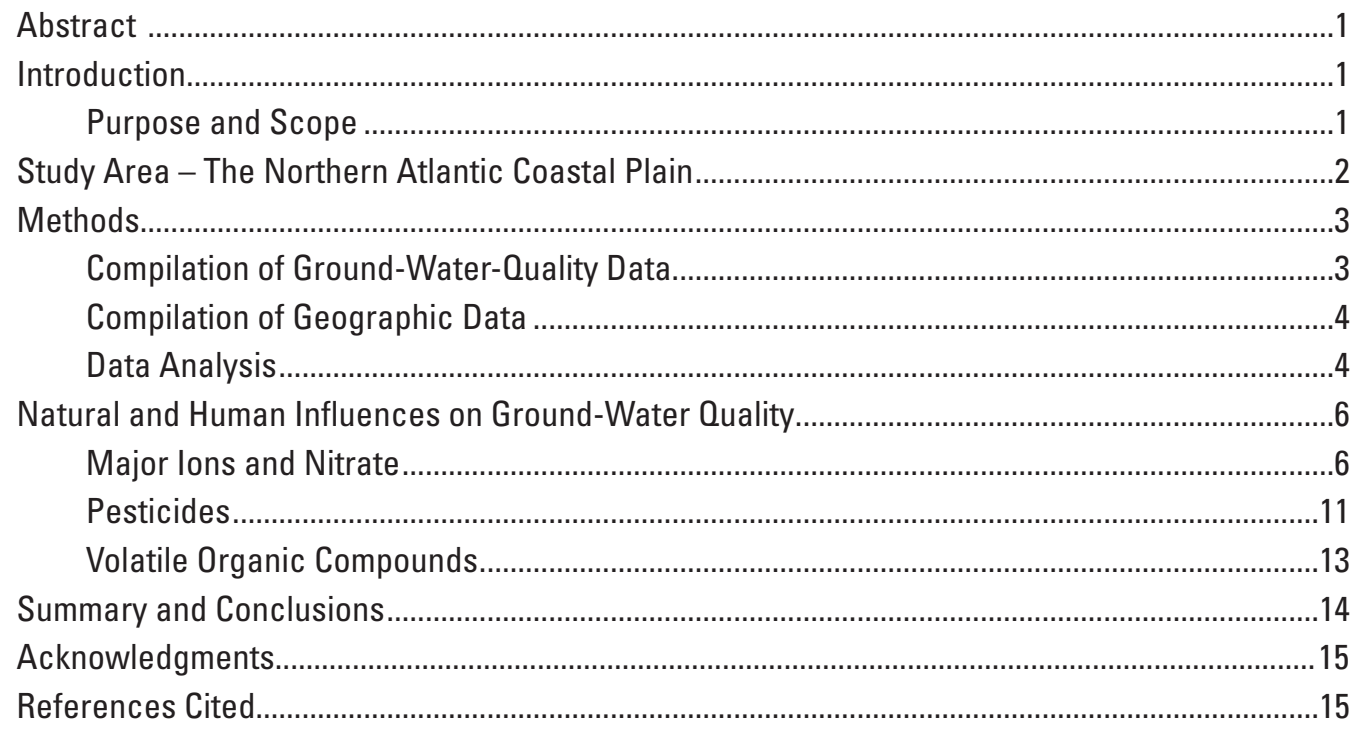

\section{Figures}

1. Map showing sampled wells and selected hydrogeologic settings in the Northern Atlantic Coastal Plain.

2-5. Graphs showing-

2. Distribution of dissolved-oxygen concentrations in samples with complete major-ion data among three hydrogeologic subregions, Northern Atlantic Coastal Plain.

3. Summary of major-ion chemistry in samples with complete major-ion data, Northern Atlantic Coastal Plain

4. Estimated probability of nitrate concentration exceeding 0.4 milligrams per liter (as nitrogen) in samples from three hydrogeologic subregions, Northern Atlantic Coastal Plain

5. Relation of deethylatrazine concentration to ground-water redox condition (as represented by Principal Component 2) in samples from the Coastal Lowlands (Subregion 1)

\section{Tables}

1. Summary of selected hydrogeologic settings in the Northern Atlantic Coastal Plain and distribution of wells from which compiled ground-water-quality data were collected

2. Summary of selected characteristics of ground-water-quality data compiled for the Northern Atlantic Coastal Plain

3. Loadings on the first three principal components from unrotated principal components analysis.....

4. Summary of correlations (Spearman's rho) among selected water-quality and geographic variables in three hydrogeologic subregions.

5. Summary of logistic regression models of ground-water quality 


\section{Conversion Factors}

\begin{tabular}{lcl}
\hline Multiply & By & To obtain \\
\hline foot $(\mathrm{ft})$ & Length & \\
mile $(\mathrm{mi})$ & 0.3048 & meter $(\mathrm{m})$ \\
\hline & 1.609 & kilometer $(\mathrm{km})$ \\
\hline square mile $\left(\mathrm{mi}^{2}\right)$ & Area & hectare $(\mathrm{ha})$ \\
square mile $\left(\mathrm{mi}^{2}\right)$ & 259.0 & square kilometer $\left(\mathrm{km}^{2}\right)$ \\
\hline
\end{tabular}

Temperature in degrees Celsius $\left({ }^{\circ} \mathrm{C}\right)$ may be converted to degrees Fahrenheit $\left({ }^{\circ} \mathrm{F}\right)$ as follows: ${ }^{\circ} \mathrm{F}=\left(1.8 x^{\circ} \mathrm{C}\right)+32$

Specific conductance is given in microsiemens per centimeter at 25 degrees Celsius $(\mu \mathrm{S} / \mathrm{cm}$ at $\left.25^{\circ} \mathrm{C}\right)$.

Concentrations of chemical constituents in water are given either in milligrams per liter (mg/L) or micrograms per liter $(\mu \mathrm{g} / \mathrm{L})$. 




\title{
Natural and Human Influences on Water Quality in a Shallow Regional Unconsolidated Aquifer, Northern Atlantic Coastal Plain
}

\author{
By Scott W. Ator
}

\section{Abstract}

Data collected from more than 400 wells in the surficial unconfined aquifer in the Northern Atlantic Coastal Plain (New York through North Carolina) were compiled and analyzed to improve understanding of multiple natural and human influences on water quality in such shallow regional aquifers. Geochemical patterns were identified and described through principal components analysis on major ions, and correlation and logistic regression were used to relate observed concentrations of nitrate and selected pesticide compounds (atrazine, metolachlor, simazine, and deethylatrazine, an atrazine degradate) and volatile organic compounds (chloroform, 1,1,1-trichloroethane, tetrachlorethene, and methyl tert-butyl ether) to likely influences, such as observed geochemical patterns, land use, hydrogeology, and soils. Variability in major-ion concentrations is primarily related to ionic strength and redox condition. Concentrations of nitrate, pesticides, and volatile organic compounds are related to natural conditions, as well as the distribution of likely sources reflected in land use. Nitrate is most common in aerobic ground water and in relatively well-drained areas, for example; concentrations greater than 0.4 milligrams per liter may result from a variety of human activities, although concentrations greater than 3 milligrams per liter are more likely in agricultural areas. Atrazine, deethylatrazine, and metolachlor also are related to geochemical patterns, likely because ground-water geochemistry reflects hydrogeologic and soil conditions affecting pesticide transport to the water table. Results demonstrate the value of geochemical information along with the distribution of sources and other influences to understanding the regional occurrence of selected compounds in ground water. Such influences are not unique to the Northern Atlantic Coastal Plain, and thus observations and interpretations are relevant to broader areas.

\section{Introduction}

Synthetic organic pesticides and volatile organic compounds (VOCs) have been detected in ground water in many areas of the United States (Barbash and Resek, 1996; Barbash and others, 1999; Moran and others, 2002; Squillace and others, 2002; Gilliom and others, 2006; Zogorski and others, 2006). Ground water in many areas also contains nitrate at concentrations exceeding natural levels (Nolan and Stoner, 2000; Squillace and others, 2002). Although pesticides, VOCs, and nitrogen compounds have contributed significantly to agricultural productivity, industry, public health, transportation, and other applications, the occurrence of these compounds in ground water at certain concentrations can affect its potability (Toccalino and others, 2004), and the ecology of streams, estuaries, and other receiving waters. Understanding the interacting effects of land-use practices, soil and geologic conditions, and other natural and human factors on the occurrence and distribution of pesticides, VOCs, and nutrients in ground water at different scales can contribute to the safe and effective use of these compounds.

\section{Purpose and Scope}

Natural and human influences on the occurrence and distribution of nitrate and selected pesticides and VOCs in shallow [generally less than $10 \mathrm{~m}$ (meters) deep], unconfined ground water at the regional scale in an unconsolidated aquifer are described and discussed in this report. Regional analysis and interpretation of water quality are intended as a compromise between local studies (which may be difficult to extrapolate to wider areas) and national studies (in which detailed understanding may be limited by great variability in potential influences). Water-quality data collected from 1991 through 2003 from more than 400 wells in the surficial aquifer in the Northern Atlantic Coastal Plain in parts of North Carolina, Virginia, Maryland, Delaware, New Jersey, and New York (fig. 1) were compiled and analyzed. Geochemical patterns were identified and described through principal components analysis (PCA) on major ions and were considered along with other likely influences (such as land use and hydrogeologic and soil conditions) in statistical approaches (such as correlation and logistic regression) to understand regional ground-water quality, including pesticides and VOCs. Results are interpreted and discussed to illustrate important sources of selected compounds to ground water in different settings, geochemical, hydrogeologic, and soil conditions that affect 
the distribution of such compounds, and the importance of geochemical indicators (such as major ions) along with other data for understanding the regional occurrence of chemicals in shallow ground water.

\section{Study Area-The Northern Atlantic Coastal Plain}

The Northern Atlantic Coastal Plain includes 116,000 km² (square kilometers) of the Coastal Plain Physiographic Province (Fenneman, 1928) in the eastern United States (fig. 1). Land use and land cover in the Coastal Plain are diverse, including relatively natural forests and wetlands, as well as agriculture (including row crops and livestock production) and densely populated urban areas, particularly around Washington, D.C., and to the north. The Coastal Plain is underlain by a heterogeneous wedge of primarily unconsolidated deposits that thickens from $0 \mathrm{~m}$ at the Fall Zone to several thousand meters along the Atlantic Coast, and forms an alternating series of aquifers and confining units (Meng and Harsh, 1988; Smolensky and others, 1989; Zapecza, 1989; Vroblesky and Fleck, 1991; Trapp, 1992; Winner and Coble, 1996). Permeable surficial and near-surface deposits comprising the unconfined aquifer are generally flat-lying and unconsolidated, but vary considerably in age, texture, origin, and thickness over the region (Trapp, 1992; Ator and others, 2005). Although some unconfined ground water supplies recharge to underlying confined aquifers, most discharges directly to nearby surface waters (Leahy and Martin, 1993). Ground water generally moves through the unconfined aquifer from the water table to local discharge areas within a few decades, although residence times are considerably greater along longer, deeper flow paths in areas where the unconfined aquifer is particularly thick (Buxton and Modica, 1992; Böhlke and Denver, 1995; McFarland, 1995; Speiran, 1996; Szabo and others, 1996; Kauffman and others, 2001). Ground-water discharge as base flow contributes most of the streamflow in the Northern Atlantic Coastal Plain (Leahy and Martin, 1993), and a considerable load of nutrients to downstream estuaries and other receiving waters (Bachman and Phillips, 1996; Bachman and others, 1998).

Water quality in the unconfined aquifer has been studied at local to sub-regional scales at various locations within the Coastal Plain in recent decades. Investigations at such scales can support particularly detailed analyses of ground-water quality, but are often necessarily restricted to a limited range of hydrogeologic and land-use settings, and results may be difficult to interpret over wider areas. Although broad regional patterns related to natural geochemical processes are apparent in the water quality in confined Coastal Plain aquifers, water quality in the unconfined aquifer is typically related primarily to local conditions (particularly land use), and is therefore more spatially variable (Knobel and others, 1998). Natural ground water in the well-weathered siliciclastic sediments

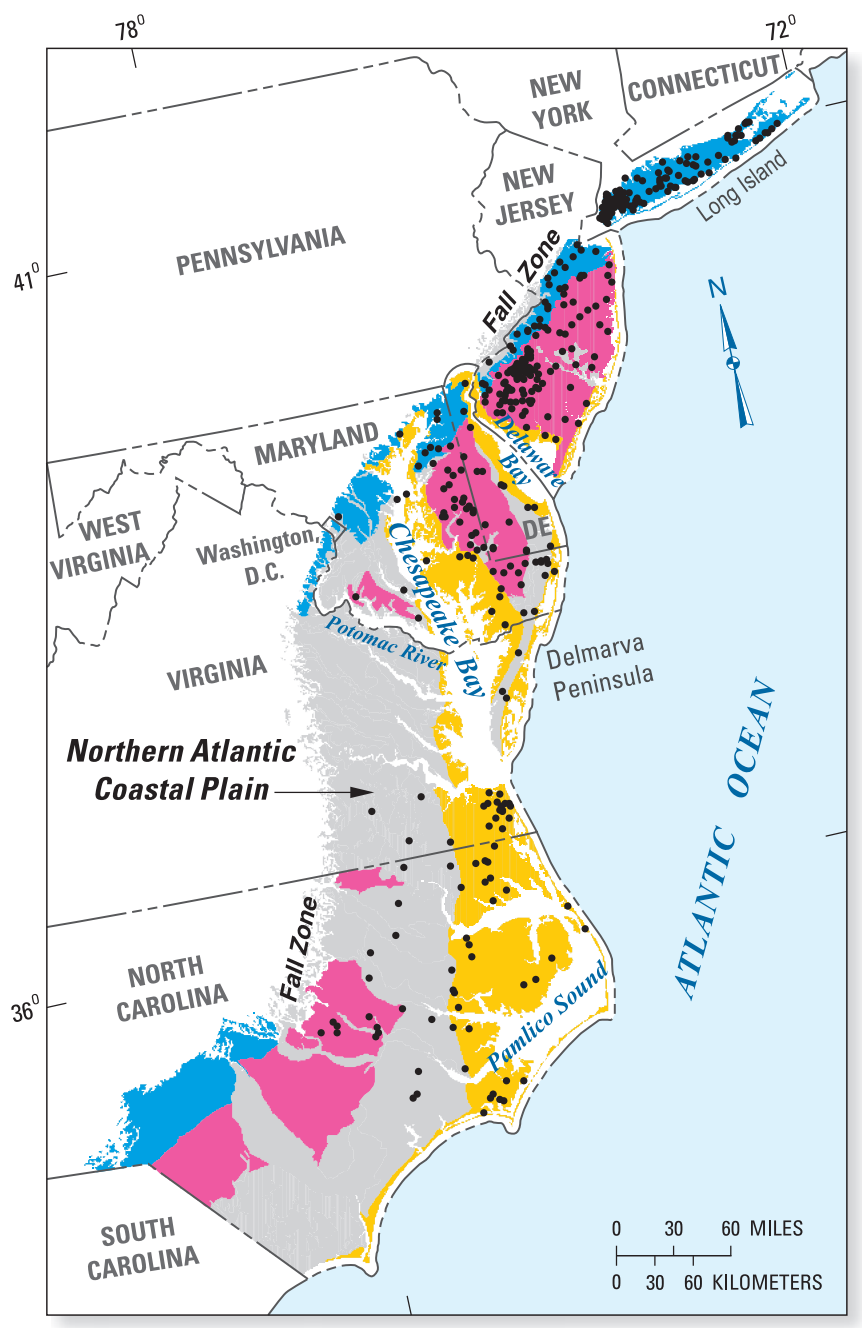

\section{EXPLANATION}

Selected hydrogeologic subregions (Modified from Smolensky and others,1989; Ator and others, 2005)

1 Coastal Lowlands

4 Middle Coastal Plain, Sands with Overlying Gravels

6 Inner Coastal Plain,

6 Dissected Outcrop Belt

Other

- Sampled well

Figure 1. Sampled wells and selected hydrogeologic settings in the Northern Atlantic Coastal Plain.

typical of many parts of the surficial aquifer is commonly relatively dilute, and may be significantly affected by chemical applications (Denver, 1989; Knobel and others, 1998; Ator and others, 2000). Effects of such applications may be less pronounced in other areas where natural sources of soluble ions in soils or shallow sediments are more common. The occurrence of nitrate attributed to human sources in parts of the aquifer has been reported since at least the early 1970s (Cushing and others, 1973; Bachman, 1984; Denver, 1989; Böhlke 
and Denver, 1995; Eckhardt and Stackelberg, 1995; Bolton, 1996; Spruill and others, 1997; Stackelberg and others, 1997; Clawges and others, 1999; Shedlock and others, 1999; Denver and others, 2004). Nitrate concentrations are generally highest in areas with permeable sediments and well-drained soils; nitrate may be removed from ground water by denitrification in anoxic areas such as poorly drained coastal or riparian wetlands (Phillips and others, 1993; Böhlke and Denver, 1995; Tesoriero and others, 2005). Ground water affected by agriculture, septic effluent, or road salting also may contain elevated concentrations of calcium, magnesium, sodium, potassium, or chloride (Denver, 1989), although some of these major ions may also be derived from natural sources, such as the dissolution of soluble minerals in soils or aquifer sediments (Tesoriero and others, 2004). Pesticide concentrations are typically less than $1 \mu \mathrm{g} / \mathrm{L}$ (microgram per liter) in the aquifer, and are greatest near areas of agricultural or urban use, and where movement into and through the ground-water system is not impeded by poorly drained or organic-rich soils or aquifer sediments (Koterba and others, 1993; Eckhardt and Stackelberg, 1995; Bolton, 1996; Stackelberg and others, 1997; Clawges and others, 1999; Stackelberg and others, 2000; Tesoriero and others, 2004). VOCs are most commonly detected in unconfined ground water near sources in urban areas (Eckhardt and Stackelberg, 1995; Stackelberg and others, 1997; Stackelberg and others, 2000; Ferrari, 2002). Concentrations are generally low (less than $1 \mu \mathrm{g} / \mathrm{L}$ ), but can vary substantially and may be considerably higher near source areas.

\section{Methods}

Data collected over a multi-year period were compiled and analyzed to describe factors affecting the occurrence and distribution of nitrate and selected pesticides and VOCs in shallow unconfined ground water at the regional scale in the Northern Atlantic Coastal Plain. Observed ground-water quality was compared to land use, soils, and other potential explanatory variables to provide insight into the interacting natural and human influences on shallow ground water in the area at the regional scale.

\section{Compilation of Ground-Water-Quality Data}

Data were compiled to support a regional interpretation of shallow, unconfined ground-water quality. Available data collected by the U.S. Geological Survey (USGS) and cooperating agencies from the early 1990s through September 2003 in the study area were evaluated for inclusion in light of the project objectives. In light of the regional scale of the interpretation, only data collected as part of regional projects or programs (covering areas generally larger than a single county) were included. In addition, only data from wells that are unused (such as observation wells) or relatively low-producing (such as domestic wells) were targeted for inclusion.
Data from wells used primarily for irrigation, public supply, or other potentially large withdrawals were avoided; such wells may draw ground water from relatively large contributing areas, and therefore complicate efforts to relate observed ground-water quality to specific land uses or other geographic variables. Data from wells installed to monitor known or suspected contamination from specific point sources were also avoided.

Ground-water-quality data for a large part of the Northern Atlantic Coastal Plain were retrieved from USGS databases from August through November 2004 and compiled to a single database. Many of these data were collected as part of the National Water-Quality Assessment (NAWQA) Program (Gilliom and others, 1995; Lapham and others, 1995; Spruill and others, 1998; Ayers and others, 2001; Denver and others, 2004; Debrewer and others, 2007); additional data were compiled from USGS cooperative-study projects (Bolton, 1996; Cartwright and others, 1998; Phillips and others, 1999; Serfes and others, 2006). Laboratory analyses for NAWQA and cooperative projects were conducted at the USGS National WaterQuality Laboratory (NWQL) in Denver, Colorado. Wells in the unconfined aquifer that were sampled for these projects are generally shallow. Because of the particularly thick unsaturated zone and unconfined aquifer in parts of Long Island, New York, compiled data from that area were restricted to samples collected from wells completed within approximately $15 \mathrm{~m}$ of the measured water table. Where measured water levels were unavailable, Long Island wells were included if less than $15 \mathrm{~m}$ deep or completed above sea level. Wells in the resulting overall dataset are generally less than $10 \mathrm{~m}$ deep (median, $9 \mathrm{~m}$ ); the water table in these wells (where reported) was generally less than $5 \mathrm{~m}$ below land surface. Although included data were collected over a span of more than 12 years (March 1991 through September 2003), all data were considered comparable for the purposes of regional interpretation. Statistically significant temporal trends in ground-water nitrate and pesticide concentrations over near-decadal time periods have been detected recently in some areas (for example, Bexfield, 2008; Debrewer and others, 2008), although temporal changes in concentrations in individual wells are typically relatively small compared to spatial differences among wells.

Specific compounds were selected for data analysis on the basis of data availability and (particularly for pesticides and VOCs) detection frequency. Pesticide data were limited to concentrations determined in filtered water samples with a single laboratory method in common use by NAWQA and other programs (Zaugg and others, 1995). Atrazine, deethylatrazine (DEA, an atrazine degradate), metolachlor, and simazine were the most commonly detected pesticide compounds in the compiled data and were therefore selected for data analysis. VOC data were restricted to samples collected after the most commonly used method for NAWQA VOC analyses in unfiltered samples (Connor and others, 1998) was fully implemented at the NWQL (October 1, 1996) to avoid potential complications in interpreting previous data with typically higher reporting levels. VOC data were further limited to samples that were 
analyzed for each of four compounds that were selected for data analysis: chloroform, 1,1,1-trichloroethane (TCA), tetrachloroethene (PCE), and methyl tert-butyl ether (MTBE). Nitrate data were limited to reported concentrations of nitrite plus nitrate as nitrogen (referred to hereinafter as "nitrate") in filtered water samples. For analyses and discussion of majorion chemistry, data were restricted to samples with reported specific conductance, $\mathrm{pH}$, and concentrations of dissolved oxygen, calcium, magnesium, sodium, potassium, iron, manganese, chloride, sulfate, nitrate, bicarbonate, and silica. Reported concentrations of cations and bicarbonate in unfiltered samples from some wells were assumed to be comparable to concentrations in filtered ("dissolved") samples from the remainder of the study area. Bicarbonate concentrations were reported from incremental field titrations; where such values were missing, bicarbonate concentrations computed from reported acid-neutralizing capacity $(\mathrm{Hem}, 1985)$ in fixedendpoint laboratory titrations were assumed to be comparable.

Compiled data were screened to limit effects of spatial bias on the results of regional analyses. Although some wells were sampled multiple times, only the most recent available data of each type (pesticide, VOC, nitrate, or major-ion) from each well were retained for analysis. These data were typically from the same sample. The geographic distribution of wells also was reviewed to maximize sample independence and to minimize spatial autocorrelation among wells in the compiled dataset (Barringer and others, 1990). Among wells located within $1,000 \mathrm{~m}$ of one another, data from only one well were retained for analysis. Wells were selected from among such clustered wells on the basis of (in decreasing order of importance) most available pesticide, VOC, nitrate, or major-ion data; shallowest; and most recent pesticide data.

\section{Compilation of Geographic Data}

Geographic data were compiled for comparison to observed ground-water quality. Land-cover data at 30-m resolution from the early 1990s (U.S. Geological Survey, 1999) were compiled to represent land uses and associated potential human effects on ground water in the study area. Potential natural influences on the quality of shallow unconfined ground water in the Coastal Plain include soil composition and hydrogeologic conditions. Schwarz and Alexander (1995) computed layer-thickness-weighted averages of selected hydrologically important soil characteristics from soils data available for the United States. A framework summarizing surficial and near-surface hydrogeologic conditions for the Mid-Atlantic Coastal Plain (Ator and others, 2005) was extended to include Long Island, New York for comparison to measured ground-water quality (fig. 1; table 1).

Proportions of various land uses and area-weighted averages of selected soil properties were computed for areas within $500 \mathrm{~m}$ of wells in the compiled dataset. Such relatively local land-use and soil conditions were selected on the assumption that ground water contributing to the primarily shallow, relatively low-pumpage wells in the dataset is derived mostly from relatively small areas near the well. Ground-water modeling coupled with particle tracking indicated that ground water contributing to selected compiled NAWQA wells in New Jersey is derived from within $500 \mathrm{~m}$ of the wells (Stackelberg and others, 2000). Greene and others (2005) found that logistic regression models relating concentrations of nitrate in ground water to selected geographic variables were strongest for 1,500-m radii, although their modeling covered a larger area of the Mid-Atlantic Region and included wells completed in fractured bedrock. Also, nitrate can be particularly stable in ground water, and might be expected to move greater distances along flow paths than other compounds such as pesticides or VOCs.

\section{Data Analysis}

Concentrations of major ions were evaluated to illustrate general patterns in major-ion geochemistry in samples of shallow unconfined ground water of the Coastal Plain. Trilinear diagrams (Helsel and Hirsch, 1992) were constructed to illustrate major cations and anions in various water types, and PCA (Hamilton, 1992) was conducted to summarize and identify underlying patterns in major-ion ground-water geochemistry. Censored data were assumed to represent zero in the construction of trilinear diagrams. PCA was run on ranks of data values to accommodate censored data. PCA has been used previously to interpret ground-water chemistry at various scales, often through interpretation of scatterplots of principal components (for example, Nolan, 1999; Stetzenbach and others, 2001; Cruz and Amaral, 2004). Dewhurst and others (2003) related principal components of ground-water chemistry in an urban area to toxicity.

Concentrations of nitrate and selected pesticides and VOCs were summarized and compared to the geochemical conditions [major-ion principal components (PCs)] and among different land uses, soils, and hydrogeologic conditions to evaluate the relative importance of various natural and human influences on regional ground-water quality. Geochemical PCs also were compared among these geographic settings. Relations between continuous variables were evaluated through examination of scatterplots and rank-transform correlation coefficients (Spearman's rho). Rank-based correlation coefficients evaluate monotonic relations and can be useful even when data are severely censored (Helsel and Hirsch, 1992). Rank-transform analysis-of-variance (ANOVA) and Tukey tests $(\alpha=0.05)$ (Helsel and Hirsch, 1992) were used to compare the distribution of continuous variables among hydrogeologic subregions.

Binary logistic regression (Helsel and Hirsch, 1992) was used to further illustrate land-use, soil, hydrogeologic, and geochemical factors related to the occurrence of selected pesticides, VOCs, and nitrate in ground water. Logistic-regression models for nitrate describe factors affecting the probability of nitrate occurring in ground water at concentrations greater 
Table 1. Summary of selected hydrogeologic settings in the Northern Atlantic Coastal Plain and distribution of wells from which compiled ground-water-quality data were collected.

[n, number of wells in compiled dataset (total=409); Tot, proportion of land use in entire subregion (in percent); Med, median percent land use within 500 meters of wells in compiled dataset; IQR, interquartile range $\left(75^{\text {th }}\right.$ percentile minus $25^{\text {th }}$ percentile) of percent land use within 500 meters of wells in compiled dataset; Agric, agriculture; <, less than]

\begin{tabular}{|c|c|c|c|c|c|}
\hline \multirow{2}{*}{$\begin{array}{l}\text { Hydrogeologic } \\
\text { Subregion }\end{array}$} & \multirow{2}{*}{ n } & \multicolumn{3}{|c|}{$\begin{array}{c}\text { Land-Use Distribution } \\
\text { [Tot / Med (IOR)] }\end{array}$} & \multirow{2}{*}{ Summary Description } \\
\hline & & Forest & Agriculture & Urban & \\
\hline 1: Coastal Lowlands & 63 & $19 / 12(23)$ & 27 / $52(52)$ & $6 / 1(19)$ & $\begin{array}{l}\text { Predominantly flat and low-lying } \\
\text { with consequent poor natural } \\
\text { drainage. Streams are typically } \\
\text { sluggish and wetlands with } \\
\text { organic-rich soils are common. } \\
\text { Water table is relatively shal- } \\
\text { low and ground water may be } \\
\text { poorly oxidized. }\end{array}$ \\
\hline $\begin{array}{l}\text { 4: Middle Coastal } \\
\text { Plain, Sands } \\
\text { with Overlying } \\
\text { Gravels }\end{array}$ & 160 & $38 / 17(29)$ & 39 / $30(69)$ & $7 / 5(64)$ & $\begin{array}{l}\text { Coarse surficial sediments and } \\
\text { moderate relief promote } \\
\text { infiltration and drainage of the } \\
\text { land surface, and oxidation of } \\
\text { shallow ground water. }\end{array}$ \\
\hline $\begin{array}{l}\text { 6: Inner Coastal } \\
\text { Plain, Dissected } \\
\text { Outcrop Belt }\end{array}$ & 144 & $42 / 6(15)$ & $22 /<1(18)$ & $28 / 85(68)$ & $\begin{array}{l}\text { Topographic relief promotes } \\
\text { runoff. Surficial sediment } \\
\text { texture and oxidation of ground } \\
\text { water is variable; some units } \\
\text { are coarse and permeable } \\
\text { while others are fine-grained. } \\
\text { Includes glacial sediments on } \\
\text { Long Island. }\end{array}$ \\
\hline
\end{tabular}

${ }^{1}$ Modified from Smolensky and others, 1989; Ator and others, 2005.

than $0.4 \mathrm{mg} / \mathrm{L}$ (milligrams per liter), a previous estimate of the maximum concentration in natural ground water in part of the Coastal Plain (Hamilton and others, 1993), and greater than $3 \mathrm{mg} / \mathrm{L}$, a concentration likely indicative of human influences. Other models describe factors affecting the probability of detecting atrazine or DEA, metolachlor, or one of the four VOCs in ground water, using sensitive analytical methods typical of NAWQA (at several nanograms per liter for the pesticide compounds, or a few tenths of a microgram per liter for the VOCs). Quantified values of pesticide compounds at any level were considered detections for the purpose of the pesticide models; such values reported by the NWQL indicate that the presence of the compound is confirmed, even if the concentration may be estimated (see below) (Gilliom and others, 2006). Explanatory variables were selected for each model using a stepwise procedure $(\alpha=0.05)$. Candidate variables included hydrogeologic subregion, well depth, geochemical PCs, dissolved oxygen, specific conductance, and selected land-use (urban, agriculture, forest, wetland) and soil (clay, organic matter, permeability, hydrologic group, drainage, slope) characteristics. Dissolved oxygen was included as a binary class variable indicating concentrations less than, or greater than or equal to, $1 \mathrm{mg} / \mathrm{L}$. Because nitrate was used to define the geochemical PCs, these PCs were excluded from consideration for the nitrate models, and all available dissolved-oxygen and specific-conductance data corresponding to nitrate observations (including those without a complete set of major-ion data) were included. Logit plots were examined for each model, and the sensitivity of the list of selected explanatory variables in each model to unusually influential or poorly fitted points was checked by rerunning the stepwise selection without such points to verify that each such selected variable remained significant.

Relations between ground-water quality and potential natural and human influences were determined for three surficial hydrogeologic subregions in the Coastal Plain - the Coastal Lowlands, the Middle Coastal Plain - Sands with Overlying Gravels (hereinafter referred to as "the Middle Coastal Plain"), and the Inner Coastal Plain - Dissected Outcrop Belt (hereinafter referred to as "the Inner Coastal Plain") (table 1). These three subregions account for the vast majority of compiled ground-water-quality data, and represent a variety 
of distinct hydrogeologic settings in the area. Because relatively few VOC data were available from the Coastal Lowlands, VOC analyses were further limited to two subregions. Geochemical PCs were considered comparable to pesticide or VOC data for use in regression or other analyses when based on concentrations measured in the same sample. Reported estimated values (such as below long-term method detection levels) were included as quantities in data analyses to maximize the scientific information in the data, although particularly low reported concentrations are less certain than higher concentrations, and the chance of false negatives is greater (L.M. Bexfield, U.S. Geological Survey, written commun., 2005; Gilliom and others, 2006; Stackelberg and others, 2006). Data were censored to a common level for each numeric variable, and censored data were set to a common lower level before ranks were computed for use in statistical analyses. Rare pesticide, VOC, or nitrate observations censored at unusually high concentrations were assumed to represent poor measurements due to sample interference or some other type of measurement issue (Gilliom and others, 2006), and were excluded from analyses. Although procedures for reporting censored pesticide values were revised at the NWQL in October 2000 (Oblinger Childress and others, 1999), censored pesticide data for the

Table 2. Summary of selected characteristics of groundwater-quality data compiled for the Northern Atlantic Coastal Plain.

[n, number of samples; $\mathrm{mg} / \mathrm{L}$, milligrams per liter; $\mu \mathrm{g} / \mathrm{L}$, micrograms per liter; DEA, deethylatrazine; TCA, 1,1,1-trichloroethane; PCE, tetrachlorethene; MTBE, methyl tert-butyl ether; <, less than]

\begin{tabular}{|c|c|c|c|c|}
\hline $\begin{array}{l}\text { Compound } \\
\text { (units) }\end{array}$ & $\mathbf{n}$ & Maximum & $\begin{array}{c}90^{\text {th }} \\
\text { Percentile }\end{array}$ & Median \\
\hline $\begin{array}{l}\text { Nitrate }(\mathrm{mg} / \mathrm{L} \\
\quad \text { as } \mathrm{N})\end{array}$ & 352 & 55.5 & 11.9 & 2.0 \\
\hline Atrazine $(\mu \mathrm{g} / \mathrm{L})$ & 346 & 4.2 & 0.017 & ${ }^{1}<0.004$ \\
\hline $\operatorname{DEA}(\mu \mathrm{g} / \mathrm{L})$ & 351 & 0.480 & 0.014 & ${ }^{1}<0.003$ \\
\hline $\begin{array}{l}\text { Metolachlor } \\
(\mu \mathrm{g} / \mathrm{L})\end{array}$ & 349 & 3.97 & 0.014 & ${ }^{1}<0.006$ \\
\hline Simazine $(\mu \mathrm{g} / \mathrm{L})$ & 346 & 4.71 & 0.014 & ${ }^{1}<0.006$ \\
\hline $\begin{array}{l}\text { Chloroform } \\
\qquad(\mu \mathrm{g} / \mathrm{L})\end{array}$ & 203 & 26.3 & 1.14 & $<0.1$ \\
\hline $\mathrm{TCA}(\mu \mathrm{g} / \mathrm{L})$ & 203 & 19.9 & $<0.1$ & $<0.1$ \\
\hline $\mathrm{PCE}(\mu \mathrm{g} / \mathrm{L})$ & 202 & 805 & 0.27 & $<0.1$ \\
\hline MTBE $(\mu \mathrm{g} / \mathrm{L})$ & 203 & 116 & 0.7 & $<0.2$ \\
\hline
\end{tabular}

\footnotetext{
${ }^{1}$ Censored percentiles for pesticides are listed as less than the maximum long-term method detection level for the study period (Gilliom and others, 2006).
}

entire period of study were considered equivalent (Gilliom and others, 2006), and such censored concentrations were assumed to be less than the lowest quantified values when computing ranks for statistical tests (L.M. Bexfield, U.S. Geological Survey, written commun., 2005). Effects of including such particularly low pesticide concentrations as quantities in data analyses on results and data interpretation are minimal; results of analyses of pesticide data using this approach and using data recensored up to maximum long-term method detection levels for the study period (see table 2) were very similar.

\section{Natural and Human Influences on Ground-Water Quality}

Ground-water quality in the unconfined aquifer in the Northern Atlantic Coastal Plain is related to natural and human influences in local areas. Land use, soil, and hydrogeologic conditions near (within $500 \mathrm{~m}$ of) sampled wells impart observable effects on shallow ground water. Concentrations of major ions and nitrate are particularly variable in the Coastal Plain; this variability among compiled data can be explained by a limited number of geochemical factors related to land use, soils, and hydrogeologic conditions. Observed pesticide, VOC, and nitrate concentrations are also related to geochemical conditions, as well as land use, soils, and hydrogeology.

\section{Major lons and Nitrate}

Water in much of the surficial aquifer in the Coastal Plain is well-oxidized and reflects the influence of soluble ions from natural or human sources at or near the land surface. Although ground water is dilute in some areas, the median specific conductance among 272 samples with complete major-ion data was $247 \mu \mathrm{S} / \mathrm{cm}$ (microsiemens per centimeter), considerably higher than would be expected in many areas from precipitation and mineral dissolution alone (Denver, 1989). Similarly, reported $\mathrm{pH}$ in these samples ranged from 3.7 to 8.5 , but the median of 5.4 likely reflects the buffering of precipitation with ions from natural or human sources (Denver, 1989). Dissolved oxygen is abundant in many areas (sample median, $3.8 \mathrm{mg} / \mathrm{L}$ ), although concentrations were less than $1 \mathrm{mg} / \mathrm{L}$ in samples from 75 of 272 wells. The generally lower dissolvedoxygen concentrations observed in the Coastal Lowlands than in the Middle or Inner Coastal Plain (fig. 2) reflects the poor drainage, organic-rich soils, and relatively reducing conditions common in that hydrogeologic setting (fig. 1; table 1).

The major-ion composition of unconfined ground water in the Coastal Plain varies from place to place, reflecting associated spatial variability in natural and human sources of major cations and anions (fig. 3). Dominant cations are typically calcium or sodium in most of the 272 samples; dominant anions typically vary from bicarbonate to chloride and nitrate. Magnesium and sulfate are generally minor components of 
sampled unconfined ground water in the Coastal Plain (fig. 3). Although ground-water chemistry may vary with land use or other influences in each hydrogeologic setting, major-ion composition among compiled samples is relatively consistent in the Middle Coastal Plain, where major anions are commonly limited primarily to chloride and nitrate. In contrast, major-ion composition in the Coastal Lowlands is particularly variable; ground water in this subregion varies from a calcium-bicarbonate type to the calcium-sodium-chloride-nitrate type more typical of the other subregions (fig. 3).

Nitrate concentrations reflect human inputs of nitrogen in many areas of the Northern Atlantic Coastal Plain. Although reported nitrate concentrations were less than $0.06 \mathrm{mg} / \mathrm{L}$ in more than one quarter of the wells in the compiled dataset, concentrations vary considerably among different areas of the Coastal Plain, and nitrate is a dominant anion in some samples. Nitrate concentrations as high as $55.5 \mathrm{mg} / \mathrm{L}$ were reported; the median was about $2 \mathrm{mg} / \mathrm{L}$ (table 2). Although concentrations of nitrate attributable to natural sources are uncertain and likely vary spatially, most previous estimates

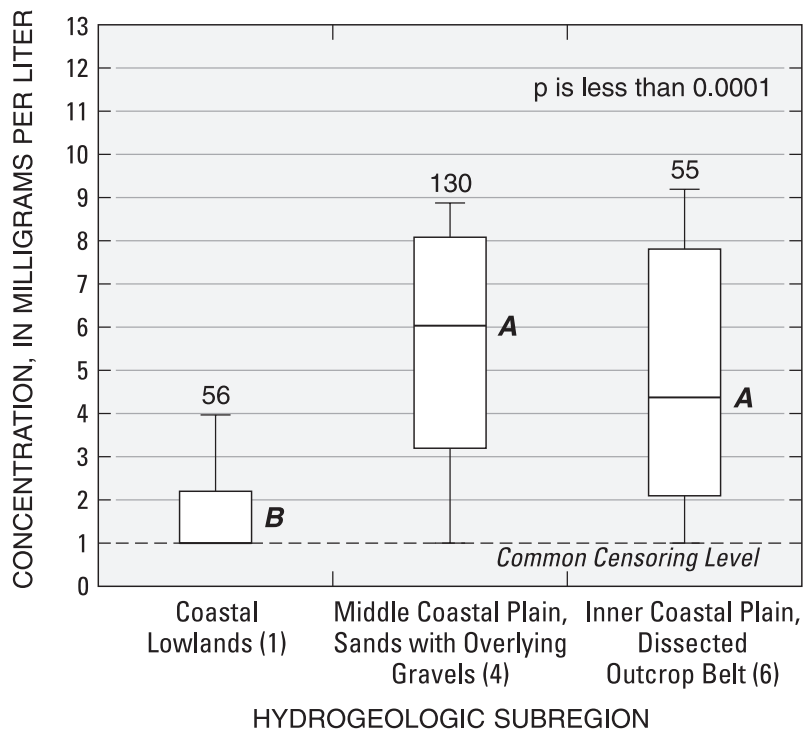

\section{EXPLANATION}

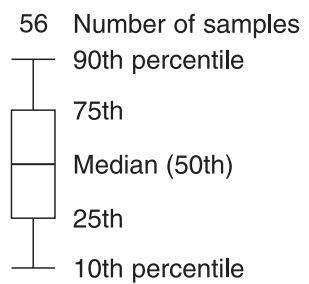

Figure 2. Distribution of dissolved-oxygen concentrations in samples with complete major-ion data among three hydrogeologic subregions, Northern Atlantic Coastal Plain. [Listed p-value and letters in plot reflect results of rank-transform ANOVA and Tukey tests. Groups with the same letter are not significantly different.] for areas of the Coastal Plain are less than $1 \mathrm{mg} / \mathrm{L}$ (Hamilton and others, 1993; Stackelberg and others, 2000). Nitrate may affect the potability of untreated ground water in some areas of the surficial aquifer; reported nitrate concentrations in samples from 52 of 352 wells were greater than $10 \mathrm{mg} / \mathrm{L}$, the current Federal standard for drinking water (U.S. Environmental Protection Agency, 2004).

Variability in major-ion composition in unconfined ground water in the Coastal Plain is related primarily to a limited number of factors. Specific conductance, $\mathrm{pH}$, and concentrations of dissolved oxygen, calcium, magnesium, sodium, potassium, iron, manganese, chloride, sulfate, nitrate, bicarbonate, and silica are generally correlated with one another, and PCA indicates that three components explain more than 70 percent of the variability in these observations in the compiled dataset (table 3 ). The first component (PC1) explains 40 percent of the variability in major-ion composition, and apparently represents an indicator of overall ionic strength. Strong positive loadings for $\mathrm{PC} 1$ are greatest for specific conductance, and also include most of the major cations (calcium, magnesium, and sodium) and anions (chloride and bicarbonate) measured in Coastal Plain ground water. The second principal component (PC2), which explains 22 percent of the variability in major-ion composition, is apparently an indicator of redox condition. PC2 has relatively strong positive loadings for nitrate and dissolved oxygen (indicative of oxygen-rich ground water), and relatively strong negative loadings for iron (which is most soluble under reducing conditions). The third principal component (PC3) explains only 9 percent of the variability in major-ion composition, and may be an indicator of different sources of soluble ions to ground water. Calcium, bicarbonate, and $\mathrm{pH}$ (suggestive of the dissolution of lime, shell material, or other carbonate minerals) have relatively strong positive loadings for PC3. Ions with relatively strong negative loadings for PC3 include manganese, sodium, chloride, and sulfate (table 3 ).

The major-ion composition of unconfined ground water is related to different land-use and soil factors in different areas of the Coastal Plain. Major ions contributing to the overall ionic strength of ground water are likely derived from different sources important to water quality in different settings. Ionic strength ( $\mathrm{PC} 1)$ is positively correlated with agriculture near (within $500 \mathrm{~m}$ of) sampled wells in the Middle Coastal Plain, and with urban land near sampled wells in the Inner Coastal Plain (table 4). Ionic strength is not related to urban or agricultural land use in the Coastal Lowlands, where PC1 is more strongly related to soil conditions (table 4 ). The positive correlation of ionic strength with soil clay content (and related negative correlation with permeability) apparent in all three hydrogeologic subregions may be indicative of natural sources of soluble major ions, but may also be related to correlations between land use and soil conditions in some areas. Clay content is positively correlated with agriculture among wells in the Middle Coastal Plain, and with urban land use among wells in the Inner Coastal Plain. Ionic strength is not related to agricultural or urban land use in the Coastal Lowlands, 


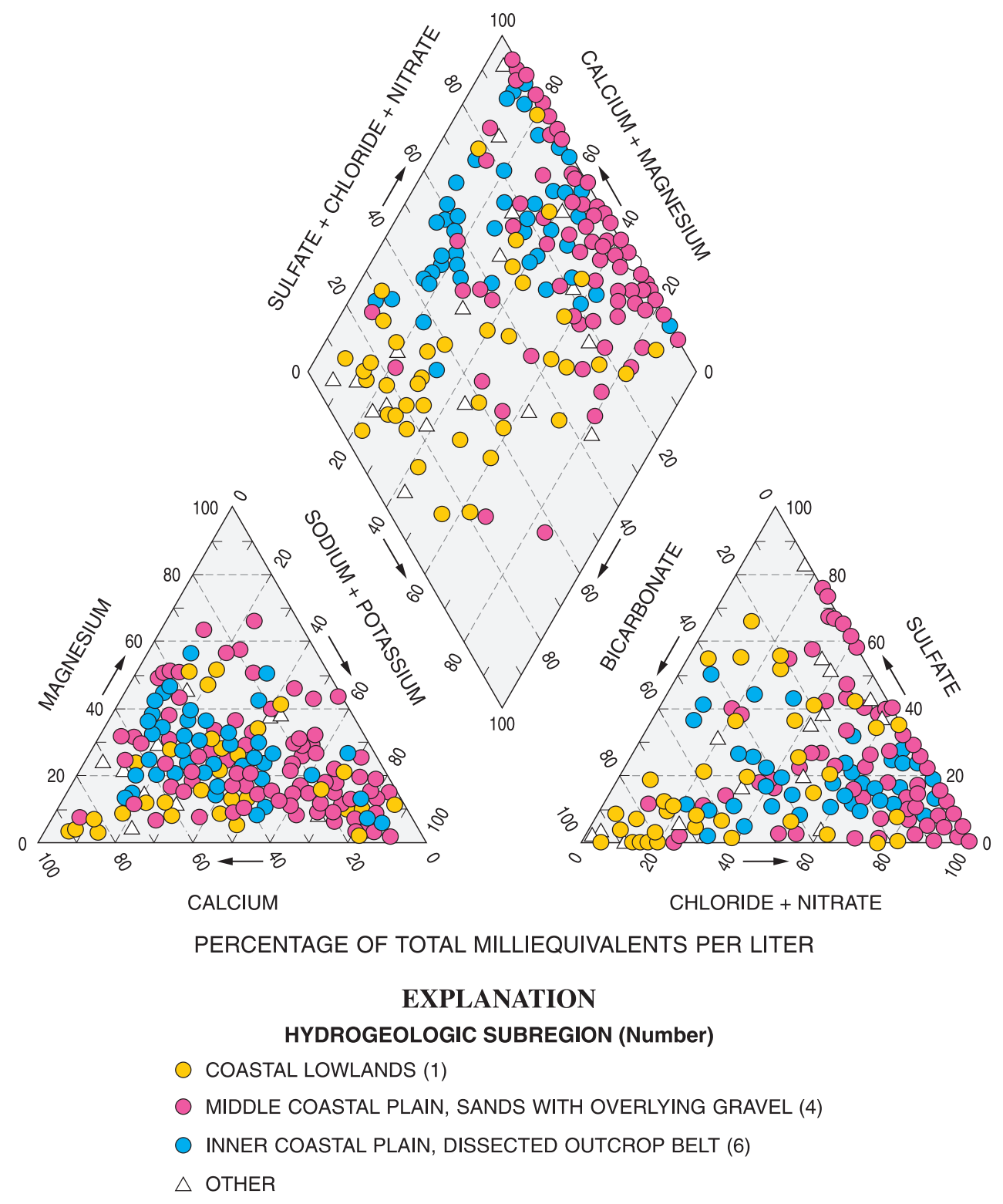

Figure 3. Summary of major-ion chemistry in samples with complete major-ion data, Northern Atlantic Coastal Plain. 
Table 3. Loadings ${ }^{1}$ on the first three principal components from unrotated principal components analysis.

[Loadings with absolute value greater than 0.60 are shown in bold; loadings with absolute value less than than 0.25 are omitted. PC; principal component]

\begin{tabular}{|c|c|c|c|}
\hline $\begin{array}{l}\text { Principal component } \\
\text { (interpretation) }\end{array}$ & $\begin{array}{c}\text { PC1 } \\
\text { (ionic } \\
\text { strength) }\end{array}$ & $\begin{array}{c}\text { PC2 } \\
\text { (redox } \\
\text { condition) }\end{array}$ & $\begin{array}{c}\text { PC3 } \\
\text { (source } \\
\text { of ions) }\end{array}$ \\
\hline $\begin{array}{l}\text { Proportion of variance } \\
\text { explained }\end{array}$ & 0.40 & 0.22 & 0.09 \\
\hline Specific conductance & 0.90 & 0.31 & \\
\hline Calcium & 0.82 & 0.25 & 0.28 \\
\hline Magnesium & 0.77 & 0.47 & \\
\hline Sodium & 0.76 & & -0.29 \\
\hline Chloride & 0.75 & 0.36 & -0.28 \\
\hline Bicarbonate & 0.76 & -0.36 & 0.46 \\
\hline $\mathrm{pH}$ & 0.69 & -0.41 & 0.52 \\
\hline Silica & 0.68 & -0.32 & \\
\hline Nitrate & & 0.84 & \\
\hline Dissolved oxygen & -0.38 & 0.70 & \\
\hline Iron & 0.50 & -0.68 & \\
\hline Manganese & 0.44 & -0.30 & -0.53 \\
\hline Sulfate & 0.46 & 0.47 & -0.26 \\
\hline Potassium & 0.39 & 0.48 & \\
\hline
\end{tabular}

${ }^{1}$ Loadings quantify relations between principal components and original variables (Hamilton, 1992).

however, and the positive correlation between PC1 and clay content suggests ions contributing to ionic strength may be derived from natural sources in relatively clay-rich soils or associated impermeable or poorly weathered sediments in that subregion. Such conditions also may contribute soluble ions to ground water where they occur in the other subregions.

Ground-water redox condition and other geochemical properties also vary among different land-use, soil, and hydrogeologic settings in the Coastal Plain. Redox condition (PC2) is correlated most strongly to land use and soil properties among sampled wells in the Middle Coastal Plain, possibly because PC2 is most variable in this subregion. Ground water in this subregion is typically more reducing (and contains correspondingly less nitrate) in more poorly drained forested or wetland areas with greater organic matter and lower slopes (table 4). In contrast, ground water is more oxic (with more nitrate) in more agricultural areas of the Middle Coastal Plain, which also typically contain more clay-rich and impermeable soils. In the Coastal Lowlands, reducing conditions in ground water are similarly associated with poorly drained, organicrich soils near sampled wells (table 4). Ion source (PC3) is most strongly related to land use and soil conditions in the Inner Coastal Plain, where negative values of PC3 (related to manganese, sodium, chloride, and sulfate) are most common in more poorly drained, organic-rich wetlands. Correlations also suggest calcium-bicarbonate waters are more common at greater depths in the Coastal Lowlands and Inner Coastal Plain, and are weakly related to agriculture in the Middle Coastal Plain (table 4).

The occurrence of nitrate at different concentrations in unconfined ground water is related to similar hydrogeologic and geochemical conditions, but possibly different sources, in different parts of the Coastal Plain. Results of correlations of nitrate concentrations to land use and soil conditions in the Coastal Lowlands and Middle Coastal Plain are similar to those for redox condition (PC2) (table 4), as might be expected given that $\mathrm{PC} 2$ has a high positive loading for nitrate (table 3 ). These results suggest that nitrate is related to natural redox conditions related to soils and (presumably) hydrogeology in these subregions, and to primarily agricultural sources, at least in the Middle Coastal Plain. Comparisons of nitrate to land use and soil characteristics in the Inner Coastal Plain, however, demonstrate some (generally weak) correlations that were not apparent for redox condition (PC2). The negative correlation of nitrate with natural forest and wetland, and the lack of a significant correlation with either specifically urban or agricultural land use, suggest that nitrate may be derived from a variety of urban or agricultural activities in this subregion. Nitrate concentrations in sampled wells in the Inner Coastal Plain also increase with decreasing soil organic matter and permeability, but increasing drainage (table 4), conditions typical of less forested or wetland areas near sampled wells in that subregion.

Regression models (table 5) further illustrate natural and human factors important to the occurrence of nitrate in sampled ground water. Nitrate is significantly more likely to exceed both $0.4 \mathrm{mg} / \mathrm{L}$ and $3 \mathrm{mg} / \mathrm{L}$ where ground water contains at least $1 \mathrm{mg} / \mathrm{L}$ of dissolved oxygen (table 5). Nitrate is also less likely to exceed estimated natural levels $(0.4 \mathrm{mg} / \mathrm{L})$ in the Coastal Lowlands than in the Middle or Inner Coastal Plain (fig. 4), as might be expected in light of the hydrogeologic and reducing conditions typical of the Coastal Lowlands (table 1, fig. 2). Similarly, nitrate concentrations greater than 3 $\mathrm{mg} / \mathrm{L}$ are more likely in areas with better soil drainage. Nitrate also is more likely to exceed both $0.4 \mathrm{mg} / \mathrm{L}$ and $3 \mathrm{mg} / \mathrm{L}$ in less forested areas, although the likelihood of nitrate concentrations greater than $3 \mathrm{mg} / \mathrm{L}$ is also specifically related to the occurrence of agriculture. The negative specific conductance term in the $0.4-\mathrm{mg} / \mathrm{L}$ model suggests that sources of nitrate at this concentration are different from possible sources of high conductance or ionic strength (such as road salt). 
Table 4. Summary of correlations (Spearman's rho) among selected water-quality and geographic variables in three hydrogeologic subregions.

[Results are shown only where $\mathrm{p}<0.05$. Shaded cells indicate $\mathrm{p}<0.01 .+$, rho positive; -, rho negative; nc, not computed; PC, principal component (PC1, ionic strength; PC2, redox condition; PC3, source of ions); DEA, deethylatrazine; MTBE, methyl tert-butyl ether; TCA, 1,1,1-trichloroethane; PCE, tetrachlorethene; <, less than]

\begin{tabular}{|c|c|c|c|c|c|c|c|c|c|c|c|c|c|c|}
\hline \multirow[b]{3}{*}{$\begin{array}{l}\text { Compound } \\
\text { or Principal } \\
\text { Component }^{1}\end{array}$} & \multicolumn{14}{|c|}{ Geographic or other potential explanatory characteristic } \\
\hline & \multicolumn{4}{|c|}{ Land use } & \multicolumn{6}{|c|}{ Soils } & \multicolumn{4}{|c|}{ Other } \\
\hline & 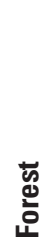 & 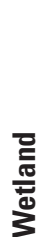 & $\begin{array}{l}\text { 등 } \\
\text { 은 }\end{array}$ & 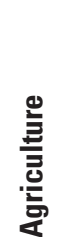 & 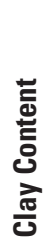 & 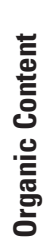 & 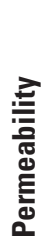 & $\begin{array}{l}\text { ㅡㅡㅁ } \\
\text { ㅎํㄴ } \\
\text { 음 } \\
\text { 음 } \\
\text { 촘 }\end{array}$ & 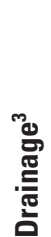 & $\frac{\Xi}{\text { 음 }}$ & 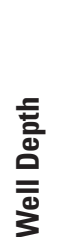 & ర్ర & ગ્ર & ঙ্র \\
\hline
\end{tabular}

Subregion 1 - Coastal Lowlands

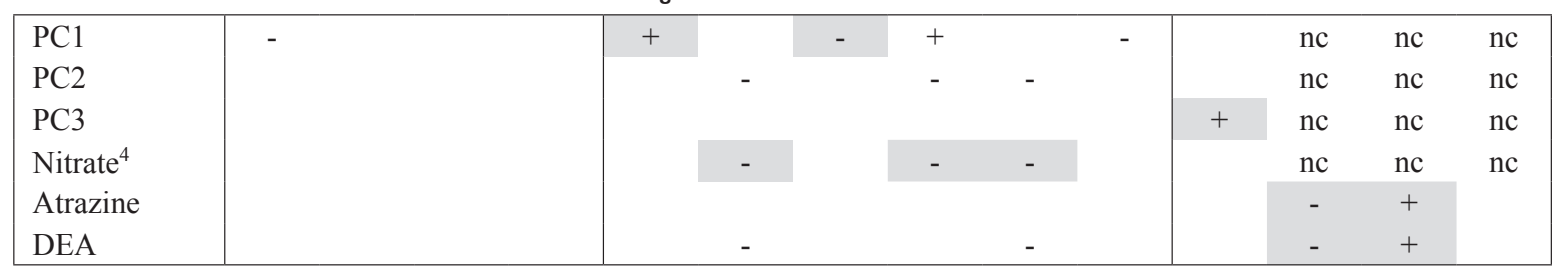

Subregion 4 - Middle Coastal Plain, Sands with Overlying Gravels

\begin{tabular}{|c|c|c|c|c|c|c|c|c|c|c|c|c|c|}
\hline PC1 & - & & & + & + & & - & & + & & nc & $\mathrm{nc}$ & nc \\
\hline PC2 & - & - & & + & + & - & - & - & + & & $\mathrm{nc}$ & nc & $\mathrm{nc}$ \\
\hline PC3 & & & & + & & & - & & & & nc & $\mathrm{nc}$ & $\mathrm{nc}$ \\
\hline Nitrate $^{4}$ & - & - & & + & + & - & - & - & + & + & nc & $\mathrm{nc}$ & nc \\
\hline Atrazine & - & - & & + & + & - & - & - & + & & & + & + \\
\hline DEA & - & - & & + & + & - & - & & + & & + & + & + \\
\hline Metolachlor & - & & - & + & + & - & & & + & & & + & \\
\hline Simazine & - & - & + & & & & & & & & & + & \\
\hline Chloroform & & - & & - & & & + & & & & - & & \\
\hline MTBE & & & + & & & & & & & & & & \\
\hline
\end{tabular}

Subregion 6 - Inner Coastal Plain, Dissected Outcrop Belt

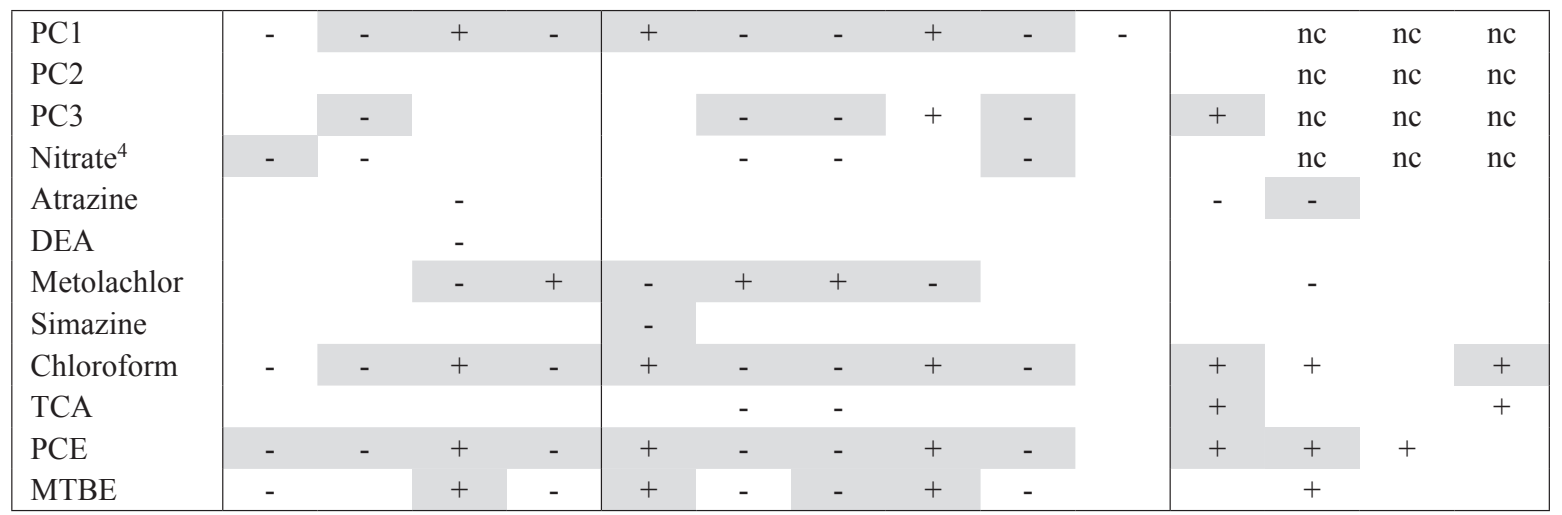

${ }^{1}$ Compounds are omitted in subregions where $\mathrm{n}<20$ or more than 90 percent of data are censored.

${ }^{2}$ Lower values indicate higher infiltration rates.

${ }^{3}$ Values range from 1 (excessive drainage) to 7 (very poor drainage).

${ }^{4}$ Results of correlations of nitrate with PCs are not shown because nitrate was used in principal components analysis (see table 3). 
Table 5. Summary of logistic regression models of ground-water quality.

[c, concordance; mg/L, milligrams per liter; >, greater than; DEA, deethylatrazine; PC, principal component (PC1, ionic strength; PC2, redox condition; PC3, source of ions); VOC, volatile organic compound]

\begin{tabular}{|c|c|c|c|c|}
\hline Response variable & $\begin{array}{c}\text { Response } \\
\text { profile } \\
\text { (yes/no) }\end{array}$ & $\begin{array}{l}\text { Explanatory variables } \\
\text { (sign of parameter) }\end{array}$ & c & $\begin{array}{c}\text { Hosmer / } \\
\text { Lemeshow } \\
\text { Goodness } \\
\text { of fit (p) }\end{array}$ \\
\hline \multirow[t]{4}{*}{$\mathrm{P}($ nitrate $>0.4 \mathrm{mg} / \mathrm{L}$ as $\mathrm{N})$} & $169 / 96$ & Percent forest (-) & 0.91 & 0.12 \\
\hline & & Specific conductance (-) & & \\
\hline & & Dissolved oxygen $^{2}$ & & \\
\hline & & Hydrogeologic subregion $^{3}$ & & \\
\hline \multirow[t]{4}{*}{$\mathrm{P}($ nitrate $>3 \mathrm{mg} / \mathrm{L}$ as $\mathrm{N})$} & $122 / 143$ & Percent forest (-) & 0.84 & 0.35 \\
\hline & & Soil drainage (-) & & \\
\hline & & Percent agriculture $(+)$ & & \\
\hline & & Dissolved oxygen ${ }^{2}$ & & \\
\hline \multirow[t]{4}{*}{$\mathrm{P}$ (atrazine or DEA detected) } & $82 / 125$ & $\mathrm{PC} 2(+)$ & 0.86 & 0.47 \\
\hline & & Percent agriculture $(+)$ & & \\
\hline & & PC1 (-) & & \\
\hline & & PC3 (+) & & \\
\hline \multirow[t]{3}{*}{ P (metolachlor detected) } & $42 / 167$ & $\mathrm{PC} 2(+)$ & 0.86 & 0.21 \\
\hline & & Percent agriculture $(+)$ & & \\
\hline & & PC1 (-) & & \\
\hline \multirow[t]{3}{*}{$\mathrm{P}\left(\mathrm{VOC}^{4}\right)$} & $66 / 75$ & Percent urban $(+)$ & 0.84 & 0.51 \\
\hline & & Percent wetland (-) & & \\
\hline & & Percent forest $(+)$ & & \\
\hline
\end{tabular}

\footnotetext{
${ }^{1}$ Continuous variables are listed in decreasing order of the absolute value of the standardized estimate, followed by class variables.

${ }^{2}$ Estimated probability is greater where dissolved-oxygen concentration is greater than or equal to $1 \mathrm{mg} / \mathrm{L}$.

${ }^{3}$ Estimated probability is greater in the Middle Coastal Plain, Sands with Overlying Gravels (subregion 4), and the Inner Coastal Plain, Dissected Outcrop Belt (subregion 6), than in the Coastal Lowlands (subregion 1).

${ }^{4}$ Probability that chloroform, tetrachlorethene (PCE), 1,1,1-trichlorethane (TCA), or methyl tert-butyl ether (MTBE) is detected above common censoring level.
}

\section{Pesticides}

Atrazine and DEA were the most commonly detected pesticide compounds in samples from the unconfined aquifer. These compounds were detected in 30 and 31 percent, respectively, of the approximately 350 samples that were analyzed for pesticides. Metolachlor and simazine were detected in 23 and 18 percent of samples, respectively. Concentrations rarely exceeded $1 \mu \mathrm{g} / \mathrm{L}$, and were generally well below $0.1 \mu \mathrm{g} / \mathrm{L}$ (table 2). No other pesticides were detected in at least 15 percent of samples, and only three others (prometon, p,p' DDE, and dieldrin) were detected in as many as 5 percent. Although individual compounds are infrequently detected, at least one of the four most commonly detected compounds was detectable in nearly half ( 46 percent) of the 338 samples for which data for each were available. Where present in unconfined ground water, pesticide compounds typically occur in mixtures. More than two-thirds ( 68 percent) of samples with detectable concentrations of atrazine, DEA, metolachlor, or simazine contained more than one of these compounds. The most common mixtures contained atrazine and its degradate, DEA, followed by metolachlor and simazine. Although pesticide concentrations are typically low, isolated higher concentrations may affect the potability of untreated ground water in some areas. 
Concentrations were greater than Federal drinking-water standards (U.S. Environmental Protection Agency, 2004) for atrazine in one sample and for simazine in two samples; such standards do not exist for metolachlor, DEA, or mixtures of compounds.

Concentrations of selected pesticides in ground water in different parts of the Coastal Plain are related to application patterns reflected in local land use. In the Middle and Inner Coastal Plain, concentrations of atrazine, DEA, and (or) metolachlor generally increase with increasing proportion of agriculture near sampled wells (table 4). Logistic models indicate that the occurrence of these compounds in ground water is also more likely in areas with a greater proportion of agriculture (table 5), as might be expected given the agricultural uses of atrazine and metolachlor (Gilliom and others, 2006). Simazine is positively correlated with urban land in the Middle Coastal Plain, and is not significantly correlated with land use in the Inner Coastal Plain. Atrazine, DEA, metolachlor, and simazine were infrequently detected in samples from the Coastal Lowlands, and atrazine and DEA are not significantly correlated with land use in that subregion (table 4).

Pesticide concentrations in unconfined Coastal Plain ground water are related to natural soil and geochemical

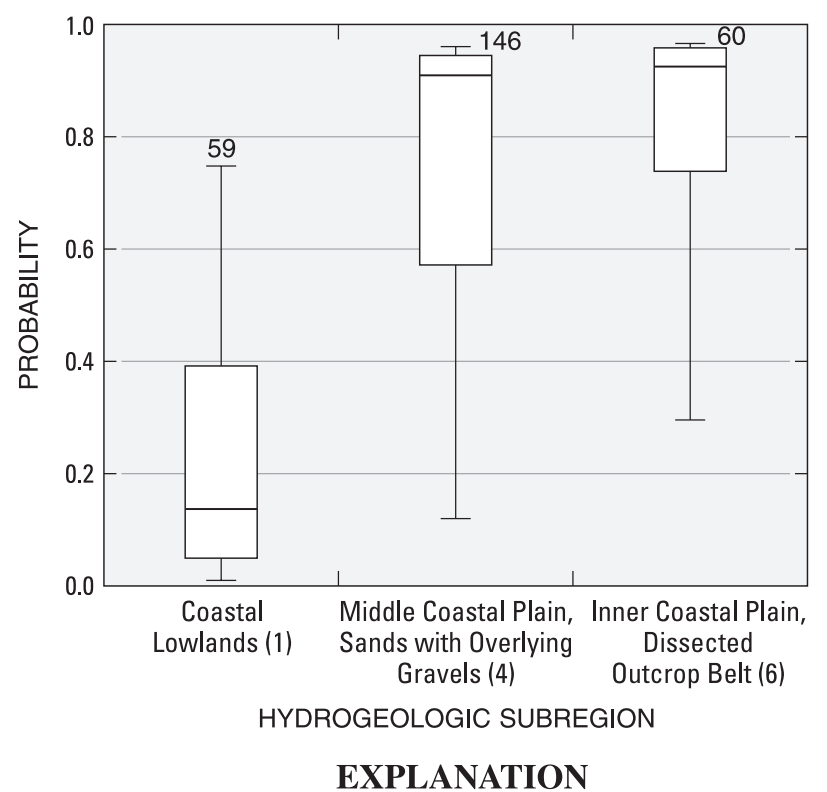

59 Number of samples

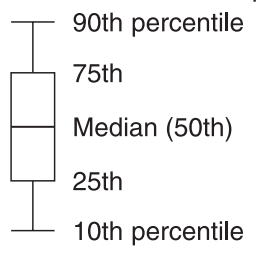

Figure 4. Estimated probability of nitrate concentration exceeding 0.4 milligrams per liter (as nitrogen) in samples from three hydrogeologic subregions, Northern Atlantic Coastal Plain. conditions, as well as land use. Organic matter may retard the transport of pesticides to ground water in some areas. Concentrations of atrazine, DEA, and (or) metolachlor decrease with increasing soil organic matter in the Coastal Lowlands and Middle Coastal Plain (table 4). A negative correlation between agriculture and soil organic matter near sampled wells may at least partly explain this relation in the Middle Coastal Plain. Similarly, the positive correlation between metolachlor concentration and organic matter in the Inner Coastal Plain may be related to a positive correlation between organic matter and agriculture among wells in that subregion. Organic matter is not related to agriculture among wells in the Coastal Lowlands, however, and the observed correlation between organic matter and DEA concentration suggests this compound may be sorbed onto organic compounds in the soils (Barbash and Resek, 1996), at least in that subregion. DEA concentrations also increase with increasing drainage in samples from the Coastal Lowlands, even though agriculture is more common in poorly drained areas. Atrazine concentrations also increase with increasing soil drainage near sampled wells in the Middle Coastal Plain, and metolachlor and simazine concentrations increase with decreasing soil clay content in the Inner Coastal Plain (table 4). Apparent correlations between pesticide concentrations and other soil variables in these subregions are likely related to similar correlations with the occurrence of agriculture.

Pesticide concentrations are also related to ground-water geochemistry in some areas of the Coastal Plain. Geochemical conditions reflected in PCs were the only significant terms other than agricultural land use in the pesticide logistic regression models (table 5). Pesticide concentrations are generally greater in more oxic ground water. Correlations between pesticide concentrations and ground-water redox condition (PC2) are positive and significant among samples in the Middle Coastal Plain, and even in the Coastal Lowlands, where pesticides were infrequently detected (table 4, fig. 5). Atrazine (or DEA) and metolachlor are also more likely to occur in oxic ground water than in areas with lower PC2 (table 5). These compounds are also more likely to be found in ground water with lower ionic strength (PC1) (table 5), and significant correlations between pesticide concentrations and ionic strength are negative in the Coastal Lowlands and Inner Coastal Plain (table 4). As discussed earlier, major ions contributing to ionic strength are likely derived (at least in part) from agricultural sources in samples from the Middle Coastal Plain, but from other sources in those from the Coastal Lowlands and Inner Coastal Plain. Although DEA concentrations are positively correlated with ionic strength in the Middle Coastal Plain (table 4), ground-water samples from this subregion were generally more dilute (lower ionic strength, ANOVA $\mathrm{p}<0.0001)$ than in the other subregions. The presence of atrazine (or DEA) is also more likely in areas with calciumbicarbonate ground water (higher PC3) (table 5), and atrazine and DEA concentrations are positively correlated with PC3 in the Middle Coastal Plain (table 4). 


\section{Volatile Organic Compounds}

VOC data were compiled for approximately 200 wells on the Delmarva Peninsula and to the north in New Jersey and New York (table 2). Samples from about half (48 percent) of these wells contained at least $0.1 \mu \mathrm{g} / \mathrm{L}$ of chloroform, PCE, or $\mathrm{TCA}$, or $0.2 \mu \mathrm{g} / \mathrm{L}$ of MTBE, and 19 percent contained more than one of these compounds at these concentrations. Chloroform was the most commonly detected individual compound at these concentrations, although only 35 percent of samples contained at least $0.1 \mu \mathrm{g} / \mathrm{L}$. The frequencies of occurrence of PCE and TCA at $0.1 \mu \mathrm{g} / \mathrm{L}$ or greater were less than 15 percent. Although VOC concentrations were typically low in sampled ground water, locally higher concentrations may affect the potability of untreated ground water in some areas. One sample contained MTBE at a concentration greater than 70 $\mu \mathrm{g} / \mathrm{L}$, a drinking-water standard in New Jersey (Toccalino and others, 2004), and seven samples contained PCE at concentrations exceeding $5 \mu \mathrm{g} / \mathrm{L}$, a Federal drinking-water standard (U.S. Environmental Protection Agency, 2004).

VOCs in sampled unconfined ground water in the Coastal Plain occur most commonly near urban areas. As might be expected, considering the sources and uses of VOCs (Moran and others, 2002), correlations with reported concentrations of chloroform, MTBE, and PCE (where significant) are generally positive with urban land use and negative with other land uses (table 4). VOC occurrence is also more likely in urban areas and less likely near wetlands in the Middle and Inner Coastal Plain (table 5). Measured concentrations of TCA rarely exceeded $0.1 \mu \mathrm{g} / \mathrm{L}$ in any subregion, and correlations between concentrations of this compound and land use are generally insignificant (table 4).

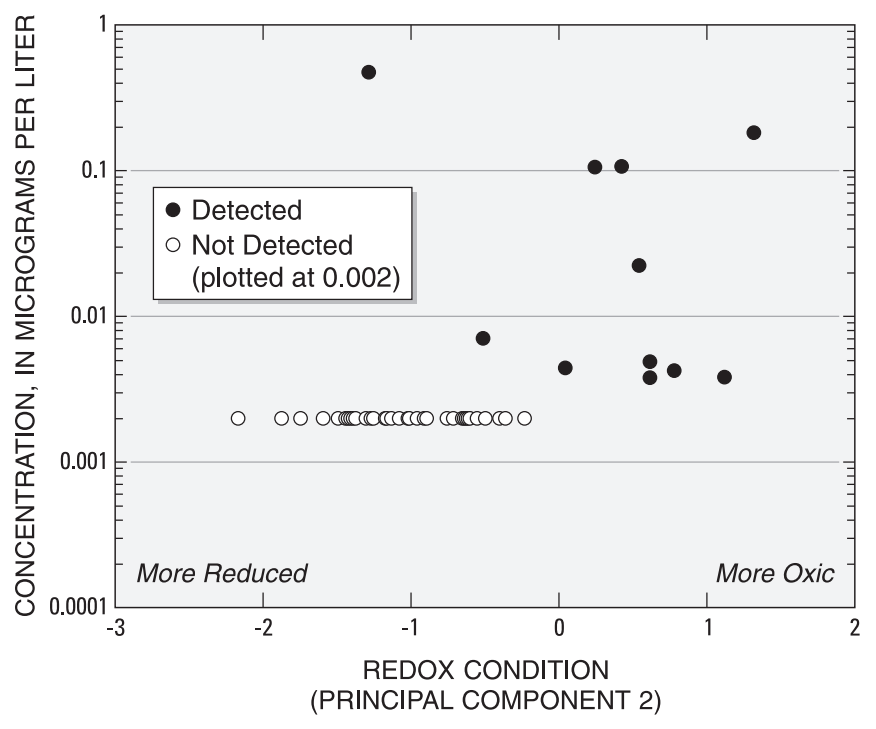

Figure 5. Relation of deethylatrazine concentration to groundwater redox condition (as represented by Principal Component 2) in samples from the Coastal Lowlands (Subregion 1).
Although human sources of VOCs to ground water are likely important, chloroform may also be derived from natural sources (Moran and others, 2002; McCulloch, 2003; Ivahnenko and Barbash, 2004). In the presence of the positive urban and negative wetland terms, logistic regression also detected a smaller (based on the standardized parameter estimate) but significant positive relation between forest and the occurrence of VOCs (table 5). This may reflect natural sources of chloroform in a particular hydrogeologic setting; forest was not selected as a significant term in a similar model for which chloroform was omitted from the definition of the dependent variable. Although only 17 of 141 wells included in the VOC model (table 5) are in predominantly (greater than 50 percent within $500 \mathrm{~m}$ ) forested areas, chloroform was detected in samples from six of these wells in the Middle Coastal Plain in New Jersey. The chloroform in ground water at these sites may have been from human sources; chloroform has been detected in septic-tank effluent (Moran and others, 2002), and three of these samples also contained detectable PCE or pesticides. The specific conductance of each of these six samples was less than $70 \mu \mathrm{S} / \mathrm{cm}$, however, which suggests minimal human influence. Chloroform may form naturally from biomass burning or from organic matter degradation in acidic forest soils (Moran and others, 2002; McCulloch, 2003; Ivahnenko and Barbash, 2004). Acidic soils and forest fires are particularly common in much of the forest of the New Jersey Coastal Plain (New Jersey Pinelands Commission, 2006).

VOC occurrence in Coastal Plain ground-water samples is also related to soil and geochemical conditions, although the relative importance of these natural conditions and land use may be difficult to determine from compiled data. Concentrations of chloroform, MTBE, and PCE in samples from the Inner Coastal Plain generally increase with decreasing soil organic matter, permeability, and infiltration, but increasing clay content and drainage (table 4). Concentrations of VOCs are also generally greater at greater depths in the Inner Coastal Plain. Although the fate and transport of VOCs in ground water may be affected by natural hydrogeologic conditions represented by these variables, the significance of these correlations may also be related to the distribution of land uses. Among wells in the compiled dataset, urban land use is also positively correlated with drainage and depth in the Inner Coastal Plain, and negatively correlated with soil organic matter, permeability, and infiltration. The interpretation of significant correlations between VOC concentrations and geochemical indicators may be similarly complicated by the relations between geochemistry and land use. Concentrations of selected VOCs are positively correlated with ionic strength (PC1) in the Inner Coastal Plain and negatively correlated with ionic strength in the Middle Coastal Plain (table 4), although ionic strength is also related to urban land use in the Inner Coastal Plain, and agriculture in the Middle Coastal Plain (see above). PCE concentrations increase with increasingly oxic conditions (indicated by PC2) in samples from the Inner Coastal Plain (table 4). This relation may be more meaningful than those with ionic strength; redox condition is not related to 
land use among sampled wells in the Inner Coastal Plain (table 4 ), and PCE is more stable in ground water under oxic conditions (Zogorski and others, 2006). Similarly, chloroform and TCA concentrations increase with increasing calcium-bicarbonate type waters (indicated by PC3) in the Inner Coastal Plain. PC3 and urban land use are not correlated in the Inner Coastal Plain, although both are correlated with well depth.

\section{Summary and Conclusions}

The quality of shallow unconfined ground water is related to the availability of chemicals from natural or human sources at or near the land surface, as well as to natural hydrogeologic and geochemical conditions that affect the transport and fate of these chemicals in the environment. Data collected recently (1991-2003) from several hundred wells in the Northern Atlantic Coastal Plain were analyzed to illustrate various influences on ground-water quality at the regional scale. Variability in observed major-ion composition is related primarily to ionic strength and redox condition. Patterns in major-ion chemistry are related to human influences, but also reflect natural geochemical and hydrogeologic conditions important to overall ground-water quality. Selected pesticide compounds [atrazine, metolachlor, simazine, and deethylatrazine (DEA), an atrazine degradate] and volatile organic compounds (VOCs) [chloroform, 1,1,1-trichloroethane (TCA), tetrachloroethene (PCE), and methyl tert-butyl ether (MTBE)] were occasionally detected, although concentrations rarely exceeded 0.2 micrograms per liter. Nitrate was also commonly detected in ground-water samples, typically at concentrations exceeding likely natural levels. Concentrations of nitrate, pesticides, and VOCs in ground water are related to chemical use in agricultural or urban areas, as well as to natural conditions that affect their movement to ground water in different settings.

Observed spatial variability in ground-water quality reflects major sources of different chemical compounds to ground water in different areas. Surficial aquifer sediments in much of the Coastal Plain are well-weathered and siliciclastic, and ground water is naturally relatively dilute. Major ions in ground water in such areas are likely derived primarily from human sources, such as agriculture in the Middle Coastal Plain, or urban sources in the Inner Coastal Plain. Major ions reflected in ionic strength may also be derived from natural sources where available in younger, more poorly weathered sediment, however, such as in parts of the Coastal Lowlands. Calcium-bicarbonate waters reflected in positive values of Principal Component 3 (PC3), for example, may be related to natural sources at depth in the Coastal Lowlands, but derived from agricultural lime applications in the Middle Coastal Plain. Nitrate at relatively low concentrations [greater than 0.4 milligrams per liter $(\mathrm{mg} / \mathrm{L})$ ] may be derived from a variety of human sources, although higher concentrations (greater than $3 \mathrm{mg} / \mathrm{L}$ ) are more common in agricultural areas. Sources of synthetic compounds, such as pesticides and VOCs, are related to patterns of human use, including agriculture for atrazine, DEA, and metolachlor, and urban uses for VOCs and (possibly) simazine. Chloroform may also form naturally in some settings.

Understanding the distribution of chemical compounds in ground water requires consideration of natural geochemical, hydrogeologic, and soil conditions, as well as the distribution of sources reflected in land use. The importance of dissolved oxygen to the occurrence and transport of nitrate in ground water is well understood and documented, and is reflected in the greater predicted likelihood of nitrate exceeding 0.4 $\mathrm{mg} / \mathrm{L}$ or $3 \mathrm{mg} / \mathrm{L}$ in relatively oxic ground water in the Coastal Plain. Nitrate is also more likely in ground water in relatively well-drained areas, such as the Middle and Inner Coastal Plain. Pesticides are also more likely in relatively oxic ground water, probably because well-drained, organic-poor soils and sediments that promote oxygen-rich ground water also typically favor the transport of soluble pesticides to the water table. The importance of ionic strength [(reflected in Principal Component 1 (PC1)] to pesticide occurrence suggested by the logistic models may also reflect that pesticides may be transported relatively easily in areas (such as the Middle Coastal Plain) with well-drained, well-weathered sediments and, therefore, relatively dilute ground water. Similar hydrogeologic and geochemical conditions may affect the transport and transformation of VOCs in ground water, although these relations were generally not apparent in the compiled data, possibly because VOC data were abundant in a less diverse group of settings. Although soil conditions are also commonly related to the occurrence of nitrate, pesticides, or VOCs in ground water, the detection of such relations in the compiled dataset may have been complicated by the correlation of soil conditions with other potential explanatory variables (notably land use). A more thorough and complete understanding of interacting land-use, soil, hydrogeologic, and geochemical factors affecting ground-water quality would likely require a particularly well-designed study, rather than a compilation of available data.

A combination of geochemical information with available geographic data can be useful for understanding and predicting the occurrence of certain chemical compounds in ground water. Geochemical conditions reflected in PCs or dissolvedoxygen concentrations were significant predictors of nitrate and pesticide occurrence in the compiled dataset. Where available, such data may provide more insight into the occurrence of these compounds than land use, soil conditions, or other geographic variables alone. Even limited measurements (such as specific conductance and dissolved-oxygen concentrations) may thus provide a useful and cost-effective summary of geochemical conditions for understanding ground-water quality.

A review of major-ion chemistry may be particularly useful for understanding the occurrence of selected chemical compounds in ground water. Principal components of majorion chemistry reflecting geochemical conditions such as ionic strength and redox condition were more predictive of the occurrence of pesticides in sampled ground water than corre- 
sponding individual measurements (specific conductance and dissolved-oxygen concentration, respectively) alone.

Geochemical conditions reflected in PCs were also the only factors other than agricultural land use that were selected for inclusion in the pesticide logistic regression models (table 5). The apparent utility of these variables is likely a result of the summary of natural and human influences on ground water that is reflected in concentrations of major ions. Dissolved oxygen alone may reflect natural conditions in ground water conducive to pesticide transport, for example, whereas dissolved oxygen along with other ions such as nitrate may reflect such natural conditions as well as potential sources (such as agriculture). Major-ion chemistry may thus identify ground water that has been affected by certain sources, rather than ground water that is merely vulnerable to such sources (D.W. Bolton, Maryland Geological Survey, written commun., 2003). Concentrations of major ions may be particularly informative in areas such as the Coastal Plain, where natural ground water is relatively dilute, but may be less so in other areas (such as carbonate aquifers), where ground-water chemistry is dominated by natural sources.

Information about interacting influences on ground-water quality provides a conceptual basis for predicting groundwater quality in wider areas. Analyses described herein were designed and intended to expand the understanding of natural and human influences on regional ground-water quality, and not to provide quantitative predictions for unsampled areas. Also, although data to support these analyses were compiled from a broad range of land-use, hydrogeologic, and other settings, these data do not represent the entire range of conditions in the Coastal Plain or other areas. Insights provided by these and similar analyses at different scales, however, support a conceptual model of ground-water quality that might be expected in wider areas. Natural ground water, for example, is likely relatively dilute and acidic in permeable, well-weathered sediments, but may be more concentrated in younger or poorly drained sediments with more abundant soluble minerals. Nitrate would be expected only in aerobic ground water most likely in well-drained areas, and may be derived from a variety of human sources, although relatively high concentrations might be expected in areas of agricultural nutrient applications. Synthetic compounds such as pesticides and most VOCs would be expected primarily downgradient from usage areas, and where hydrogeologic and geochemical conditions promote their movement and stability in ground water.

Insights on environmental and human factors affecting ground-water quality can be applied for a number of uses. Such considerations may constitute an important first step in many environmental applications, such as land-use and waterdevelopment planning, restoration of streams or other receiving waters, establishment of local or regional water-quality standards, or the design of management practices. Information about the co-occurrence of different compounds in certain settings may also be useful for the design of similar environmental studies in the future.

\section{Acknowledgments}

This work is a product of the National Water-Quality Assessment (NAWQA) Program of the U.S. Geological Survey (USGS). The assistance of many individuals is greatly appreciated. In particular, general ideas and advice on data analysis and interpretation were provided by Judith M. Denver, Paul E. Stackelberg, Stephen A. Terracciano, and A. Jim Tesoriero of the USGS. Anne C. Neale (U.S. Environmental Protection Agency) provided patient assistance with logistic regression, and Michael J. Brayton, Dennis R. Helsel, and Jeffrey D. Martin (USGS) also provided valuable suggestions or assistance with data analysis. Thoughtful comments on this manuscript were provided by Terri L. Arnold, Tracy C. Hancock, and Paul E. Stackelberg of the USGS. Mark R. Nardi and Betzaida Reyes of the USGS assisted with geographic analysis, and Linda M. Debrewer, Jacob Gibs, Kathleen L. Hibbs, Christopher E. Schubert, and Erik L. Staub of the USGS and David W. Bolton of the Maryland Geological Survey assisted with data compilation.

\section{References Cited}

Ator, S.W., Denver, J.M., and Hancock, T.C., 2000, Relating shallow ground-water quality to surficial hydrogeology in the Mid-Atlantic Coastal Plain, in Proceedings of the National Water-Quality Monitoring Council Conference, Austin, Texas, April 25-27, 2000, p. 409-423.

Ator, S.W., Denver, J.M., Krantz, D.E., Newell, W.L., and Martucci, S.K., 2005, A surficial hydrogeologic framework for the Mid-Atlantic Coastal Plain: U.S. Geological Survey Professional Paper 1680, $44 \mathrm{p}$.

Ayers, M.A., Kennen, J.G., and Stackelberg, P.E., 2001, Water quality in the Long Island-New Jersey Coastal Drainages, New Jersey and New York, 1996-98: U.S. Geological Survey Circular 1201, 40 p.

Bachman, L.J., 1984, Nitrate in the Columbia aquifer, central Delmarva Peninsula, Maryland: U.S. Geological Survey Water-Resources Investigations Report 84-4322, 51 p.

Bachman, L.J., Lindsey, B.D., Brakebill, J.W., and Powars, D.S., 1998, Ground-water discharge and base-flow nitrate loads of nontidal streams, and their relation to a hydrogeomorphic classification of the Chesapeake Bay watershed, Middle Atlantic Coast: U.S. Geological Survey WaterResources Investigations Report 98-4059, 71 p.

Bachman, L.J., and Phillips, P.J., 1996, Hydrologic landscapes on the Delmarva Peninsula, Part 2, Estimates of base-flow nitrogen loads to Chesapeake Bay: Water Resources Bulletin, v. 32, no. 4, p. 779-791. 
Barbash, J.E., and Resek, E.A., 1996, Pesticides in ground water-Distribution, trends, and governing factors: Chelsea, Michigan, Ann Arbor Press, Inc., 588 p.

Barbash, J.E., Thelin, G.P., Kolpin, D.W., and Gilliom, R.J., 1999, Distribution of major herbicides in ground water of the United States: U.S. Geological Survey Water-Resources Investigations Report 98-4245, 57 p.

Barringer, T., Dunn, D., Battaglin, W, and Vowinkel, E., 1990, Problems and methods involved in relating land use to ground-water quality: Water Resources Bulletin, v. 26, no. 1, p. $1-9$.

Bexfield, L.M., 2008, Decadal-scale changes of pesticides in ground water of the United States, 1993-2003: Journal of Environmental Quality, v. 37, p. S226-S239.

Böhlke, J.K., and Denver, J.M., 1995, Combined use of groundwater dating, chemical, and isotopic analyses to resolve the history and fate of nitrate contamination in two agricultural watersheds, Atlantic Coastal Plain, Maryland: Water Resources Research, v. 31, no. 9, p. 2,319-2,339.

Bolton, D.W., 1996, Network description and initial waterquality data from a statewide ground-water-quality network in Maryland: Maryland Geological Survey Report of Investigations No. 60, 167 p.

Buxton, H.T., and Modica, E., 1992, Patterns and rates of ground-water flow on Long Island, New York: Ground Water, v. 30 , no. 6 , p. $857-866$.

Cartwright, R.A., Chu, A., Candela, J.L., Eagen, V.K., Monti, J., Jr., and Schubert, C.E., 1998, Ground-water quality in Kings, Queens, and western Nassau Counties, Long Island, New York, 1992-96, with geophysical logs from selected wells: U.S. Geological Survey Open-File Report 98-298, $118 \mathrm{p}$.

Clawges, R.M., Stackelberg, P.E., Ayers, M.A., and Vowinkel, E.F., 1999, Nitrate, volatile organic compounds, and pesticides in ground water-A summary of selected studies from New Jersey and Long Island, New York: U.S. Geological Survey Water-Resources Investigations Report 99-4027, $32 \mathrm{p}$.

Connor, B.F., Rose, D.L., Noriega, M.C., Murtagh, L.K., and Abney, S.R., 1998, Methods of analysis by the U.S. Geological Survey National Water Quality LaboratoryDetermination of 86 volatile organic compounds in water by gas chromatography/mass spectrometry, including detections less than reporting limits: U.S. Geological Survey Open-File Report 97-829, 78 p.

Cruz, J.V., and Amaral, C.S., 2004, Major ion chemistry of groundwater from perched-water bodies of the Azores (Portugal) volcanic archipelago: Applied Geochemistry, v. 19 , no. 3, p. 445-459.
Cushing, E.M., Kantrowitz, I.H., and Taylor, K.R., 1973, Water resources of the Delmarva Peninsula: U.S. Geological Survey Professional Paper 822, 58 p.

Debrewer, L.M., Ator, S.W., and Denver, J.M., 2007, Factors affecting spatial and temporal variability in nutrient and pesticide concentrations in the surficial aquifer on the Delmarva Peninsula: U.S. Geological Survey Scientific Investigations Report 2005-5257, 44 p.

Debrewer, L.M., Ator, S.W., and Denver, J.M., 2008, Temporal trends in nitrate and selected pesticides in Mid-Atlantic ground water: Journal of Environmental Quality, v. 37, p. S296-S308.

Denver, J.M., 1989, Effects of agricultural practices and septic-system effluent on the quality of water in the unconfined aquifer in parts of eastern Sussex County, Delaware: Delaware Geological Survey Report of Investigations No. 45, $66 \mathrm{p}$.

Denver, J.M., Ator, S.W., Debrewer, L.M., Ferrari, M.J., Barbaro, J.R., Hancock, T.C., Brayton, M.J., and Nardi, M.R., 2004, Water quality in the Delmarva Peninsula, Delaware, Maryland, and Virginia: U.S. Geological Survey Circular 1228, $30 \mathrm{p}$.

Dewhurst, R.E., Wells, N.C., Crane, M., Callaghan, A., Connon, R., and Mather, J.D., 2003, Multivariate relationships between groundwater chemistry and toxicity in an urban aquifer: Environmental Toxicology and Chemistry, v. 22, no. 11, p. $2,813-2,821$.

Eckhardt, D.A.V., and Stackelberg, P.E., 1995, Relation of ground-water quality to land use on Long Island, New York: Ground Water, v. 33, no. 6, p. 1,019-1,033.

Fenneman, N.M., 1928, Physical divisions, in U.S. Geological Survey, 1970, The national atlas of the United States of America: Washington, D.C., scale: 1:17,000,000, p. 60.

Ferrari, M.J., 2002, Occurrence and distribution of selected contaminants in public drinking-water supplies in the surficial aquifer in Delaware: U.S. Geological Survey Open-File Report 01-327, 62 p.

Gilliom, R.J., Alley, W.M., and Gurtz, M.E., 1995, Design of the National Water-Quality Assessment Program-Occurrence and distribution of water-quality conditions: U.S. Geological Survey Circular 1112, 33 p.

Gilliom, R.J., Barbash, J.E., Crawford, C.G., Hamilton, P.A., Martin, J.D., Nakagaki, N., Nowell, L.H., Scott, J.C., Stackelberg, P.E., Thelin, G.P., and Wolock, D.M., 2006, Pesticides in the Nation's streams and ground water, 1992-2001: U.S. Geological Survey Circular 1291, 172 p. 
Greene, E.A., LaMotte, A.E., and Cullinan, K.A., 2005, Ground-water vulnerability to nitrate contamination at multiple thresholds in the Mid-Atlantic Region using spatial probability models: U.S. Geological Survey Scientific Investigations Report 2004-5118, 24 p.

Hamilton, L.C., 1992, Regression with graphics-A second course in applied statistics: Belmont California, Duxbury Press, $363 \mathrm{p}$.

Hamilton, P.A., Denver, J.M., Phillips, P.J., and Shedlock, R.J., 1993, Water-quality assessment of the Delmarva Peninsula - Delaware, Maryland, and Virginia-Effects of agricultural activities on, and distribution of nitrate and other inorganic constituents in the surficial aquifer: U.S. Geological Survey Open-File Report 93-40, 87 p.

Helsel, D.R., and Hirsch, R.M., 1992, Statistical methods in water resources: Amsterdam, Elsevier Publishers, 522 p.

Hem, J.D., 1985, Study and interpretation of the chemical characteristics of natural water ( $3 \mathrm{~d}$ ed.): U.S. Geological Survey Water-Supply Paper 2254, 263 p.

Ivahnenko, T., and Barbash, J.E., 2004, Chloroform in the hydrologic system-Sources, transport, fate, occurrence, and effects on human health and aquatic organisms: U.S. Geological Survey Scientific Investigations Report 20045137, $34 \mathrm{p}$.

Kauffman, L.J., Baehr, A.L., Ayers, M.A., and Stackelberg, P.E., 2001, Effects of land use and travel time on the distribution of nitrate in the Kirkwood-Cohansey aquifer system in southern New Jersey: U.S. Geological Survey WaterResources Investigations Report 01-4117, 49 p.

Knobel, L.L., Chapelle, F.H., and Meisler, H., 1998, Geochemistry of the Northern Atlantic Coastal Plain aquifer system: U.S. Geological Survey Professional Paper 1404-L, $57 \mathrm{p}$.

Koterba, M.T., Banks, W.S.L., and Shedlock, R.J., 1993, Pesticides in shallow groundwater in the Delmarva Peninsula: Journal of Environmental Quality, v. 22, p. 500-518.

Lapham, W.W., Wilde, F.D., and Koterba, M.T., 1995, Groundwater data-collection protocols and procedures for the National Water-Quality Assessment Program-Selection, installation, and documentation of wells, and collection of related data: U.S. Geological Survey Open-File Report 95-398, $69 \mathrm{p}$.

Leahy, P.P., and Martin, M., 1993, Geohydrology and simulation of ground-water flow in the Northern Atlantic Coastal Plain aquifer system: U.S. Geological Survey Professional Paper 1404-K, $81 \mathrm{p}$.

McCulloch, A., 2003, Chloroform in the environmentOccurrence, sources, sinks, and effects: Chemosphere, v. 50 , no. 10 , p. $1,291-1,308$.
McFarland, E.R., 1995, Ground-water flow, geochemistry, and effects of agricultural practices on nitrogen transport at study sites in the Piedmont and Coastal Plain Physiographic Provinces, Patuxent River Basin, Maryland: U.S. Geological Survey Open-File Report 94-507, 78 p.

Meng, A.A., and Harsh, J.F., 1988, Hydrogeologic framework of the Virginia Coastal Plain: U.S. Geological Survey Professional Paper 1404-C, 82 p.

Moran, M.J., Lapham, W.W., Rowe, B.L., and Zogorski, J.S., 2002, Occurrence and status of volatile organic compounds in ground water from rural, untreated, self-supplied domestic wells in the United States, 1986-99: U.S. Geological Survey Water-Resources Investigations Report 02-4085, $51 \mathrm{p}$.

New Jersey Pinelands Commission, 2006, Pinelands facts, accessed April 16, 2007 at http://www.nj.gov/pinelands/ infor/fact/pinefacts.pdf.

Nolan, B.T., 1999, Nitrate behavior in ground waters of the Southeastern United States: Journal of Environmental Quality, v. 28, no. 5, p. 1,518-1,527.

Nolan, B.T., and Stoner, J.D., 2000, Nutrients in groundwaters of the conterminous United States, 1992-1995: Environmental Science and Technology, v. 34, no. 7, p. $1,156-1,165$.

Oblinger Childress, C.J., Foreman, W.T., Connor, B.F., and Maloney, T.J., 1999, New reporting procedures based on long-term method detection levels and some considerations for interpretations of water-quality data provided by the U.S. Geological Survey National Water-Quality Laboratory: U.S. Geological Survey Open-File Report 99-193, 19 p.

Phillips, P.J., Denver, J.M., Shedlock, R.J., and Hamilton, P.A., 1993, Effect of forested wetlands on nitrate concentrations in ground water and surface water on the Delmarva Peninsula: Wetlands, v. 13, no. 2, p. 75-83.

Phillips, P.J., Eckhardt, D.A., Terracciano, S.A., and Rosenman, L., 1999, Pesticides and their metabolites in wells in Suffolk County, New York, 1998: U.S. Geological Survey Water-Resources Investigations Report 99-4055, 12 p.

Schwarz, G.E., and Alexander, R.B., 1995, Soils data for the conterminous United States derived from the NRCS State Soil Geographic (STATSGO) database: U.S. Geological Survey Open-File Report 95-449, digital data.

Serfes, M.E., Bousenberry, R., and Gibs, J., 2006, New Jersey's ambient ground-water-quality monitoring networkStatus of land-use impacts to shallow ground-water quality [abs], in National Water-Quality Monitoring Council $5^{\text {th }}$ National Monitoring Conference-Conference Program and Presenter Information, May 7-11, 2006, San Jose, California, p. 429. 
Shedlock, R.J., Denver, J.M., Hayes, M.A., Hamilton, P.A., Koterba, M.T., Bachman, L.J., Phillips, P.J., and Banks, W.S.L., 1999, Water-quality assessment of the Delmarva Peninsula, Delaware, Maryland, and Virginia: Results of investigations, 1987-91: U.S. Geological Survey WaterSupply Paper 2355-A, 41 p.

Smolensky, D.A., Buxton, H.T., and Shernoff, P.K., 1989, Hydrologic framework of Long Island, New York: U.S. Geological Survey Hydrologic Investigations Atlas HA-709, 3 sheets.

Speiran, G.K., 1996, Geohydrology and geochemistry near coastal ground-water discharge areas of the Eastern Shore, Virginia: U.S. Geological Survey Water-Supply Paper 2479, 73 p.

Spruill, T.B., Eimers, J.L., and Morey, A.E., 1997, Nitratenitrogen concentrations in shallow ground water of the Coastal Plain of the Albemarle-Pamlico Drainage Study Unit, North Carolina and Virginia: U.S. Geological Survey Fact Sheet FS-241-96, 4 p.

Spruill, T.B., Harned, D.A., Ruhl, P.M., Eimers, J.L., McMahon, G., Smith, K.E., Galeone, D.R., and Woodside, M.D., 1998, Water quality in the Albermarle-Pamlico Drainage Basin, North Carolina and Virginia, 1992-95: U.S. Geological Survey Circular 1157, 36 p.

Squillace, P.J., Scott, J.C., Moran, M.J., Nolan, B.T., and Kolpin, D.W., 2002, VOCs, pesticides, nitrate, and their mixtures in ground water used for drinking water in the United States: Environmental Science and Technology, v. 36, no. 9, p. 1,923-1,930.

Stackelberg, P.E., Furlong, E.T., Meyer, M.T., Zaugg, S.D., Henderson, A.K., and Reissman, D.B., 2006, Response to comment on: Persistence of pharmaceutical compounds and other organic wastewater contaminants in a conventional drinking-water treatment plant: Science of the Total Environment, v. 354, no. 1, p. 93-97.

Stackelberg, P.E., Hopple, J.A., and Kauffman, L.J., 1997, Occurrence of nitrate, pesticides, and volatile organic compounds in the Kirkwood-Cohansey aquifer system, southern New Jersey: U.S. Geological Survey WaterResources Investigations Report 97-4241, 8 p.

Stackelberg, P.E., Kauffman, L.J., Baehr, A.L., and Ayers, M.A., 2000, Comparison of nitrate, pesticides, and volatile organic compounds in samples from monitoring and publicsupply wells, Kirkwood-Cohansey aquifer system, southern New Jersey: U.S. Geological Survey Water-Resources Investigations Report 00-4123, $51 \mathrm{p}$.
Stetzenbach, K.J., Hodge, V.F., Guo, C., Farnman, I.M., and Johannesson, K.H., 2001, Geochemical and statistical evidence of deep carbonate groundwater within overlying volcanic rock aquifers/aquitards of southern Nevada, USA: Journal of Hydrology, v. 243, no. 3, p. 254-271.

Szabo, Z., Rice, D.E., Plummer, L.N., Busenberg, E., Drenkard, S., and Schlosser, P., 1996, Age dating of shallow groundwater with chlorofluorocarbons, tritium/helium 3, and flow path analysis, southern New Jersey Coastal Plain: Water Resources Research, v. 32, no. 4, p. 1,023-1,038.

Tesoriero, A.J., Spruill, T.B., and Eimers, J.L., 2004, Geochemistry of shallow ground water in coastal plain environments in the southeastern United States-Implications for aquifer susceptibility: Applied Geochemistry, v. 19, no. 9, p. 1,471-1,482.

Tesoriero, A.J., Spruill, T.B., Mew, H.E., Jr., Farrell, K.M., and Harden, S.L., 2005, Nitrogen transport and transformations in a coastal plain watershed-Influence of geomorphology on flow paths and residence times: Water Resources Research, v. 41, doi:10.1029/2003WR002953.

Toccalino, P.L., Norman, J.E., Phillips, R.H., Kaufmann, L.J., Stackelberg, P.E., Nowell, L.H., Krietzman, S.J., and Post, G.B., 2004, Application of health-based screening levels to ground-water quality data in a state-scale pilot effort: U.S. Geological Survey Scientific Investigations Report 2004-5174, 64 p.

Trapp, H., Jr., 1992, Hydrogeologic framework of the Northern Atlantic Coastal Plain in parts of North Carolina, Virginia, Maryland, Delaware, New Jersey, and New York: U.S. Geological Survey Professional Paper 1404-G, 59 p.

U.S. Environmental Protection Agency, 2004, 2004 Edition of the drinking water standards and health advisories: U.S. Environmental Protection Agency Report 822-R-04-005, $20 \mathrm{p}$.

U.S. Geological Survey, 1999, National Land Cover Dataset 1992, accessed November 20, 2008 at http://edcwww. cr.usgs.gov/products/landcover/nlcd.html.

Vroblesky, D.A., and Fleck, W.B., 1991, Hydrogeologic framework of the Coastal Plain of Maryland, Delaware, and the District of Columbia: U.S. Geological Survey Professional Paper 1404-E, 45 p.

Winner, M.D., Jr., and Coble, R.W., 1996, Hydrogeologic framework of the North Carolina Coastal Plain: U.S. Geological Survey Professional Paper 1404-I, 106 p.

Zapecza, O.S., 1989, Hydrogeologic framework of the New Jersey Coastal Plain: U.S. Geological Survey Professional Paper 1404-B, 49 p. 
Zaugg, S.D., Sandstrom, M.W., Smith, S.G., and Fehlberg, K.M., 1995, Methods of analysis by the U.S. Geological Survey National Water Quality Laboratory-Determination of pesticides in water by $\mathrm{C} 18$ solid-phase extraction and capillary-column gas chromatography/mass spectrometry with selected-ion monitoring: U.S. Geological Survey Open-File Report 95-181, 49 p.

Zogorski, J.S., Carter, J.M., Ivahnenko, T., Lapham, W.W., Moran, M.J., Rowe, B.L., Squillace, P.J., and Toccalino, P.L., 2006, Volatile organic compounds in the Nation's ground-water and drinking-water supply wells: U.S. Geological Survey Circular 1292, 101 p. 

Prepared by West Trenton, NJ Publishing Service Center. Edited by Valerie M. Gaine.

Graphics and layout by Timothy W. Auer.

For additional information, contact:

Director, MD-DE-DC Water Science Center

U.S. Geological Survey

5522 Research Park Drive

Baltimore, MD 21228

or visit our Web site at: http://md.water.usgs.gov 
